\title{
5. Employment effects of removal of restrictions on the movement of natural persons in the ASEAN banking sector
}

\section{Huong Dinh*}

\section{INTRODUCTION}

The Association of Southeast Asian Nations (ASEAN) Economic Community (AEC) envisions a single market and production base of more than 625 million people. It would be the third largest economy in Asia and the seventh largest worldwide. Despite clear aspirations of "a free flow of skilled labor" (Papademetriou et al. 2015; Almekinders et al. 2015), progress has been slow and uneven. To accelerate this process, understanding current barriers to skilled labor mobility and gathering evidence of the benefits of freer movement of professionals within ASEAN is essential.

The banking sector is a good case study. Banking remains the most important channel for providing credit in ASEAN. On aggregate, it accounted for $82 \%$ of total financial system assets within ASEAN in 2009 (ADB 2013) and provides mostly national capital flows to all economic sectors. Over the past two decades, ASEAN members have made significant trade reforms in the banking sector to promote greater market access and provide operational flexibility - via both domestic reform and regional and global trade integration. These include the World Trade Organization (WTO) General Agreement on Trade in Services (GATS) commitments, the ASEAN Banking Integration Framework, the AEC Blueprint, and the ASEAN Agreement on the Movement of Natural Persons. ${ }^{1}$

According to the AEC Blueprint, several ASEAN countries (especially Cambodia, the Lao People's Democratic Republic, and Viet Nam) committed to removing restrictions on banking services by $2015 .^{2}$ However, restrictions on labor mobility in banking remain significant. As a skilled-labor intensive sector, banks would benefit from the freer movement of professionals. Increased skills mobility can mitigate the mismatch between supply 
and demand for labor. It also reduces the costs of providing skilled labor, thereby encouraging banking sector expansion. Banks have linkages with all other industries - especially export-oriented industries - so expanding the banking sector should have non-trivial flow-on effects from both supply and demand perspectives. On the supply side, banking sector growth would lead to a reduction in the price of financial services, reducing production costs for any industries using financial services as inputs, thereby expanding their supply. On the demand side, growth would raise banking demand for other sectors' products, thus encouraging industrial expansion as well.

This chapter evaluates the economy-wide output and employment effects of removing restrictions on the movement of natural persons in ASEAN's banking sector - a key step in freeing skilled labor. We examine how skilled labor mobility in banking would change employment across ASEAN industries in total employment and employment structure in two settings: (i) when both unskilled and skilled labor rarely shift from one industry to another; and (ii) when only unskilled labor is slow to shift. These simulations enable us to see how labor mobility impacts output and employment. Although banking trade reform here is applied only to skilled labor for foreign direct investment (FDI) financial services providers, its effects are transmitted through price markups and productivity gains (as shown in Section 3), which in turn impact production and the demand for inputsincluding unskilled and skilled labor. In the simulations, we assume variable labor supply for two reasons. First, a significant proportion of ASEAN's labor force is informal, and thus not captured in input-output tables - though from time to time labor transfers from informal to formal markets. The second reason is that ASEAN's population is generally young and growing, thus increasing labor supply.

Section 2 reviews current regulatory barriers to trade in banking services - including restrictions on the movement of natural persons in ASEAN. Section 3 describes the first-round (direct) impact of trade barriers in banking services on bank performance-both conceptually and empirically. Section 4 outlines the methodology for measuring economywide effects of removing restrictions on people mobility. Details of the data for simulation are described in Section 5. The results of the simulations are discussed in Section 6, while Section 7 concludes.

\section{CURRENT RESTRICTIONS LIMITING BANKING SECTOR GROWTH}

Despite efforts to better integrate the banking sector, ASEAN bank penetration in the region is slow (Yamanaka 2013). One of the main causes 
is barriers to trade in the banking sector-regulations against the entry and operation of ASEAN banks in other member economies (Yamanaka 2013). Based on Dee and Dinh (2009), this section discusses the restrictions on intra-ASEAN banking services.

Following the framework for assessing barriers to trade in banking services developed by McGuire and Schuele (2000), Dinh (2008) and the World Bank (undated), Dee and Dinh (2009) upgraded a questionnaire that evaluates non-prudential regulations restricting ASEAN's banking services - as delivered through the four modes of supply: (i) cross-border; (ii) movement of consumers; (iii) commercial presence; and (iv) movement of individual bank personnel, particularly intra-corporate transferees. Questionnaire responses as supplied by relevant country researchers are quantified from 0 (lowest) to 1 (highest) in terms of restriction severity for each type of regulation. The scores are then aggregated to produce summary trade restrictiveness indexes (TRIs) using the weights produced in Dinh's (2008) study. This is based on the understanding that prudential regulation has a legitimate regulatory purpose and is not the target of an AEC Blueprint liberalization initiative (which is not to say that prudential regulations could not be improved in ASEAN countries).

Figure 5.1 shows the variation in restrictions affecting banking services across ASEAN countries. Except for Singapore, Malaysia, and Indonesia,

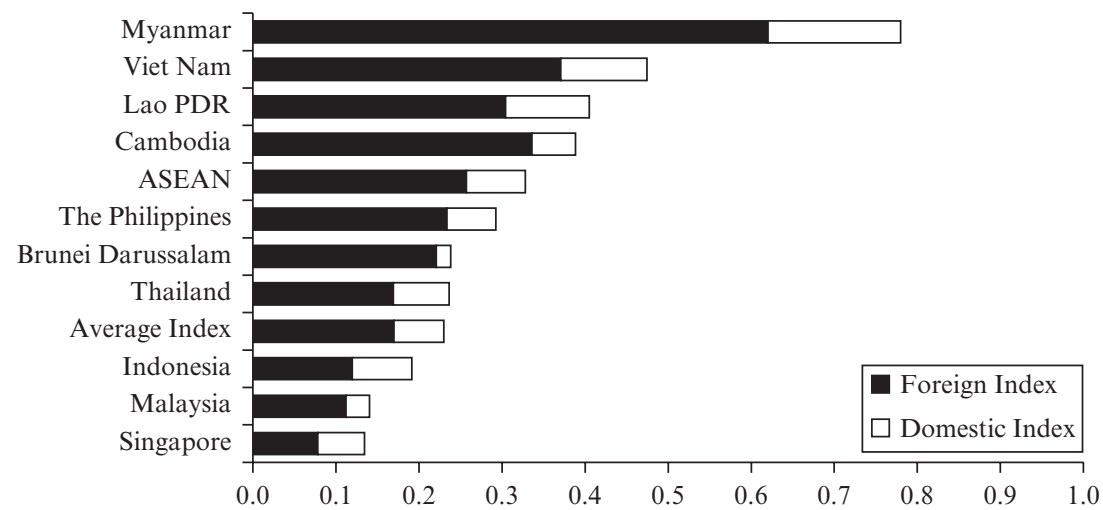

Notes:

ASEAN $=$ Association of Southeast Asian Nations; Lao PDR $=$ Lao People's Democratic Republic.

"0" indicates no restriction; "1" indicates total restriction.

Source: Dee and Dinh (2009).

Figure 5.1 Level of restrictions on banking services 
all ASEAN countries have TRIs over 0.20. The ASEAN TRI average is $0.33-0.1$, which is above the 2006 average of 36 countries as calculated in Dinh (2008). The two least restrictive countries are Singapore and Malaysia, with TRIs just above 0.1. Figure 5.1 also indicates that Myanmar and Viet Nam are the two most restrictive countries, with TRIs averaging more than 4.5 times those of Singapore and Malaysia.

Figures 5.2 and 5.3 present the prevalence of restrictions affecting FDI and domestic banks. Cross-border banking services are restricted in most ASEAN countries, while those supplied through consumer movement are limited in just a few countries. The figures indicate that broader banking services are also generally limited. Limits on operation expansion and ownership of non-financial firms are relatively common.

Figure 5.2 suggests that restrictions on the movement of people in providing services are high. At least $70 \%$ of ASEAN countries have nationality and residency requirements for the Board of Directors, restricting their stay in the host country. For example, Brunei Darussalam requires at least half of the Board of Directors of a foreign-owned bank to be nationals. In Cambodia, up to $10 \%$ of employees can be foreigners if the entity has more than ten employees. In Viet Nam, nationals must make up at least $20 \%$ of the Board of Directors.

\section{FIRST-ROUND IMPACT OF RESTRICTIONS ON THE BANKING SECTOR}

This section provides a conceptual framework for measuring first-round (direct) impacts of restrictions on the banking sector-which can be costescalating and/or rent-creating. We also present empirical estimates of the impacts.

\subsection{Cost-Escalating Impacts}

Barriers to trade in banking services can increase banks' real resource costs (Llewellyn 1986; Gowland 1990; Benston and Kaufman 1996). The key to this problem is that regulations can act as barriers, limiting competition between service providers and preventing economies of scale and scope. This can discourage service providers from operating at their lowest possible costs (Warren and Findlay 2000; Dinh 2013; Dee and Dinh 2008). The supply curve shifts upward, increasing the unit cost of service and creating a wedge between costs "with" and "without" restrictions.

Figure 5.4 shows the banking market before and after the imposition of cost-escalating restrictions. Without restrictions, the banking market 


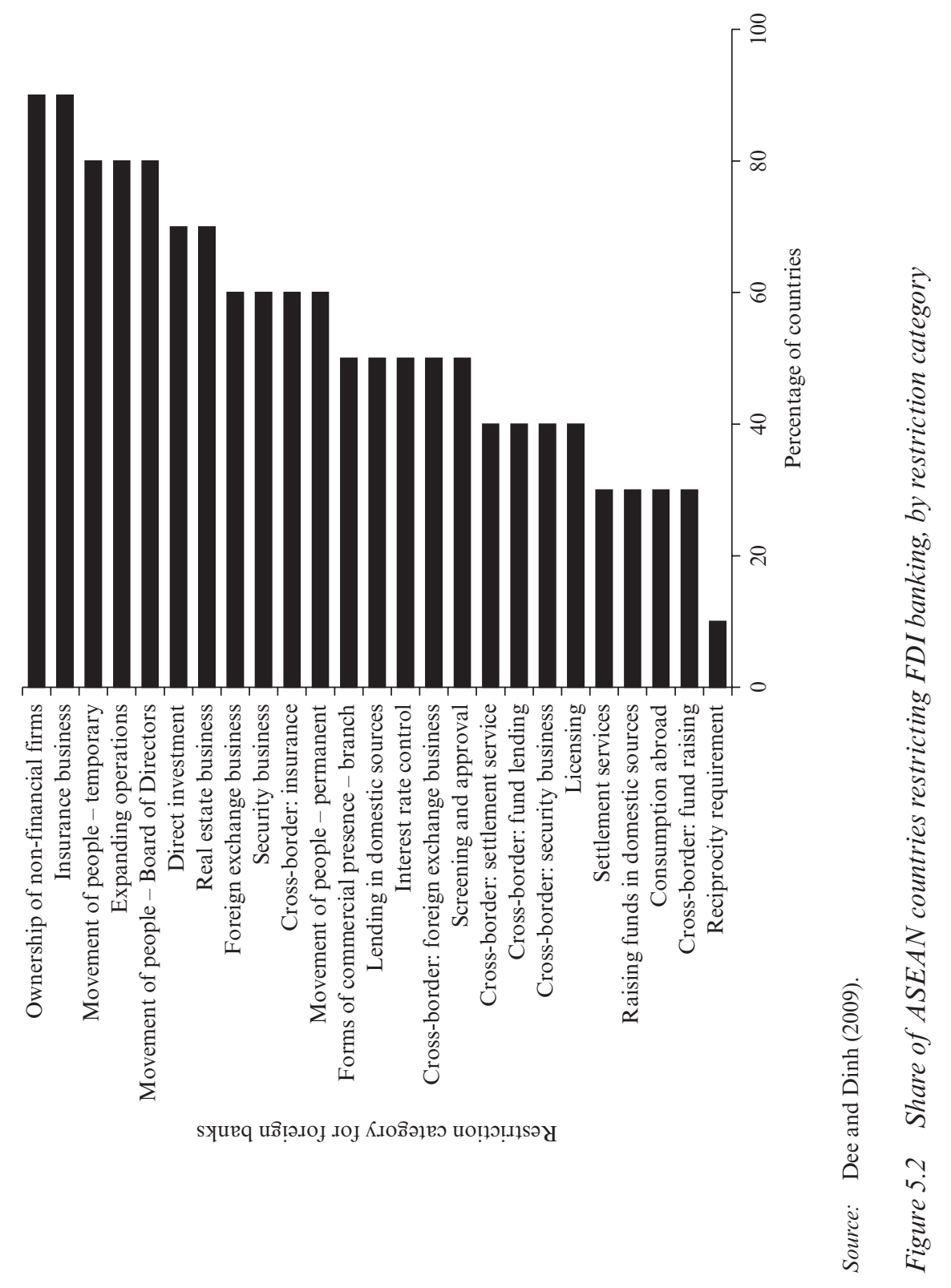




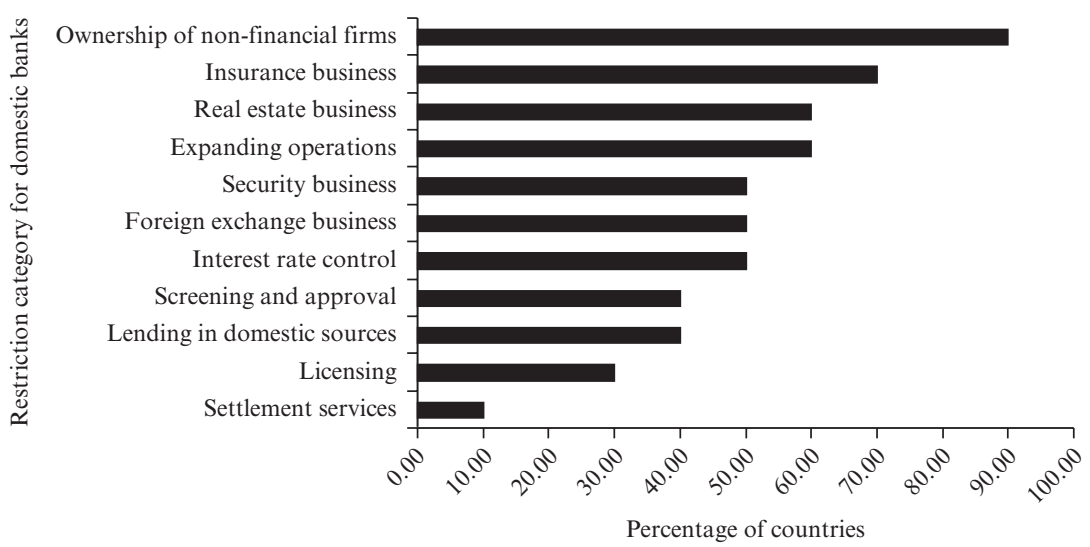

Source: Dee and Dinh (2009).

Figure 5.3 Share of ASEAN countries restricting domestic banks, by restriction category

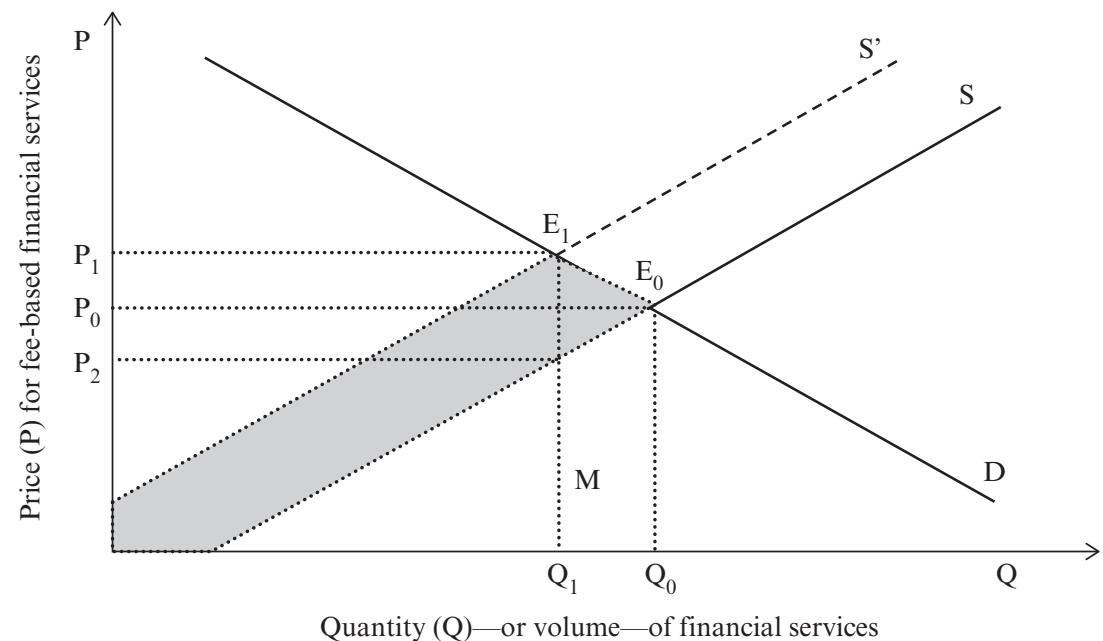

Note: $\mathrm{S}=$ supply; $\mathrm{D}=$ demand $; \mathrm{E}_{0}=$ Equilibrium without trade barriers; $\mathrm{E}_{1}=$ Equilibrium with trade barriers; $M=$ the point to identify the supply price at quantity $Q_{1}$ when there are no trade barriers.

Source: Dinh (2011).

Figure 5.4 Cost-escalating effects of trade barriers in banking services 
is in equilibrium at $\mathrm{E}_{0}$ with price $\mathrm{P}_{0}$ and output $\mathrm{Q}_{0}$. With cost-escalating restrictions, banks need to use more real resources for the same output, shifting the supply curve upward, which increases the price to $\mathrm{P}_{1}$ and reduces output to $Q_{1}$. The cost-escalating effects create a deadweight loss to society-represented by the shaded area. This loss occurs to both producers and consumers. The producer loss comes from both increased real resource costs and reduced output, whereas the consumer loss results from both increased price and reduced consumption quantity. Interestingly, in this case, there is a rise in price, but banks gain no price markup or economic rents.

\subsection{Rent-Creating Impacts}

Non-prudential regulations can also create rents for banks. They may serve the interests of the regulated banks rather than their customers (Llewellyn 1986, 1999; Benston and Kaufman 1996). This is because some restrictions may create more market power for incumbent banks, enabling them to inflate the price of financial services while real resource costs remain unchanged. As a result, banks receive higher price markups-economic rent. This rent is akin to a tax on consumers, which makes the supply curve shift upward, but the revenue flows to the incumbent banks rather than to the government (Dee 2005). A typical example would be an interest rate ceiling that creates an artificial scarcity of credit, encouraging banks to charge borrowers extra fees in addition to interest rates, thereby creating a rent for banks.

Figure 5.5 shows the banking market before and after the imposition of rent-creating barriers. Without restrictions, the banking market is in equilibrium at $\mathrm{E}_{0}$ with price $\mathrm{P}_{0}$ and output $\mathrm{Q}_{0}$. With rent-creating restrictions, banks can charge their customers a higher price at every output level, despite no change in real resource costs. This is also equivalent to an upward shift in the supply curve, resulting in new equilibrium $\mathrm{E}_{1}$. At the new equilibrium, the price rises to $P_{1}$ and output falls to $Q_{1}$. The rent-creating measures create a deadweight loss to society as represented by the shaded triangular area. The loss also consists of consumer and producer losses. The consumer loss results from both the increased price and reduced consumption quantity, while the producer loss comes only from the reduced output. In this case, the banks gain the entire price markup $\left(\mathrm{P}_{1}-\mathrm{P}_{2}\right)$ - or economic rent.

\subsection{Empirical Results}

Dinh (2013) examines whether barriers to trade in banking services create rents and/or raise real costs. The study uses panel accounting 


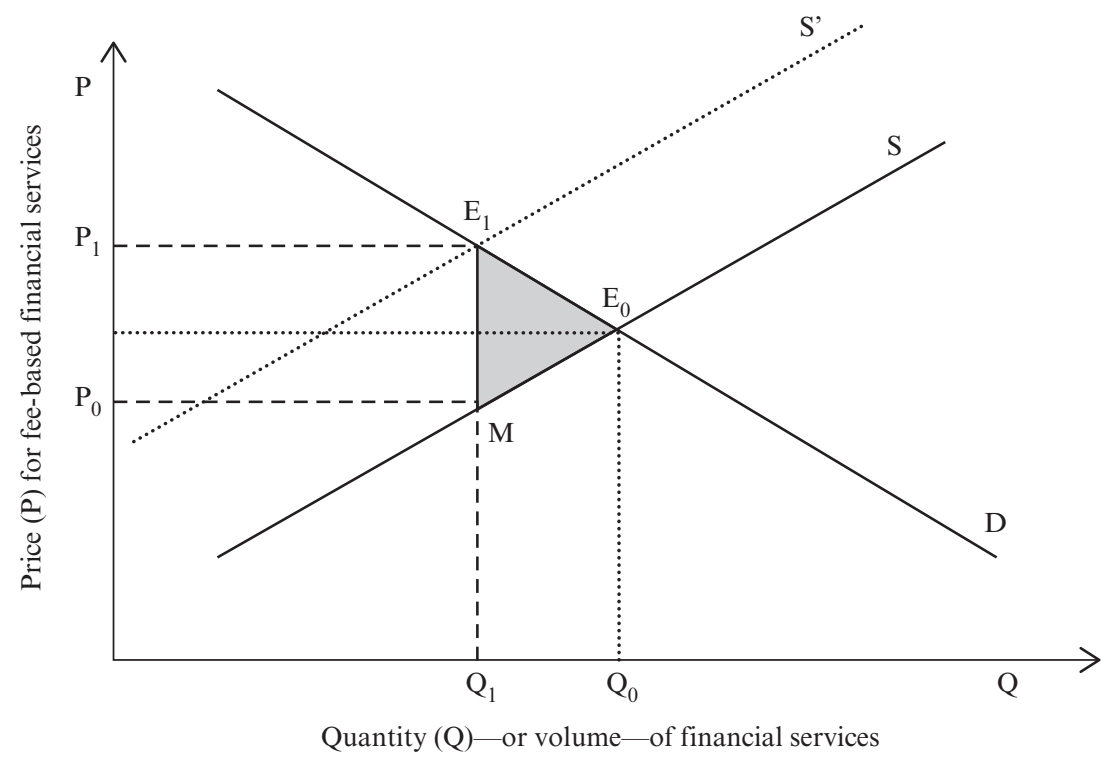

Note: $\mathrm{S}=$ supply; $\mathrm{D}=$ demand $; \mathrm{E}_{0}=$ Equilibrium without trade barriers; $\mathrm{E}_{1}=$ Equilibrium with trade barriers; $M=$ the point to identify the supply price at quantity $Q_{1}$ when there are no trade barriers.

Source: Dinh (2011).

Figure 5.5 Rent-creating impact of trade barriers in banking services

data of 7,314 commercial banks in 28 countries over 1997-2006 from Bankscope (produced by Fitch IBCA), and restrictiveness indexes in banking services constructed by Dinh (2008). Dinh adopts the Symmetric McFadden function forms for unit cost and unit profit as the key outcome variables - as this functional form is flexible, parsimonious, and regular. Dinh also applies the fixed-effect regression models with treatment of serial correlation. The Dinh (2013) results show that restrictions on bank establishment and operation - such as licensing requirements, government ownership, and restrictions on the movement of natural persons - are statistically positive determinants of both cost and profit at the $1 \%$ level of significance. In other words, restrictions on establishment and operation are both cost-escalating and rent-creating. Specifically, a 1 percentage point increase in the trade restrictiveness index on establishment and operation is estimated to raise total costs by $1.9 \%$ and improve profits by $4.8 \%$. 


\section{METHODOLOGY OF MEASURING ECONOMY- WIDE IMPACTS OF REMOVING RESTRICTIONS ON THE MOVEMENT OF NATURAL PERSONS}

The methodology involves taking the following steps:

1. Calculating banking services trade-restrictiveness indexes. Calculating these indexes for ASEAN and the rest of the word are conducted under (i) current policy settings and (ii) after removing restrictions on the movement of natural persons in the banking sector. It uses the template for measuring trade barriers in banking services and weights (the relative importance of each restriction) produced in Dee and Dinh (2009), Dinh (2011), and Dinh (2013). The current trade regime provides the baseline scenario, while the removal of restrictions on the movement of natural persons gives the counterfactual simulation policy change. Removing restrictions on the movement of natural persons is important to the banking industry as it is skilled-labor intensive.

2. Calculating productivity and tax equivalents. This calculation is a crucial step in estimating first-round effects of banking services trade barriers before and after removal of restrictions on the movement of natural persons - using the regression results produced in Dinh (2013). The productivity equivalent is measured as the percentage change in total cost of bank operations due to cost-escalating barriers to trade in banking services, compared with a scenario with no barriers. The tax equivalent is the percentage change in price markup caused by rent-creating barriers. As found in Dinh (2013), barriers to bank establishment and operation are associated with both higher costs and profits, so are modelled as productivity and tax equivalents.

3. Applying the FTAP model. As in Dinh (2012), we use the FTAP model - a comparative static, computable general equilibrium model of the world economy developed in stages from the Global Trade Analysis Project (GTAP) model - to measure the long-term economywide employment impact of trade reform in the ASEAN banking sector. Hanslow et al. (2000) highlight some key improvements in FTAP compared with GTAP. FTAP includes a treatment of FDI, thus allowing differentiation of the impacts of liberalizing restrictions on domestic banks from those on foreign ones. The FTAP model features firm-level product differentiation with large-group monopolistic competition and increasing returns to scale. It also allows for capital accumulation and international borrowing and lending (for more details, see the Appendix 5A.1: the FTAP model). As employment is the focus of this chapter, we allow labor supply in the economy 
to change - rather than fixing labor supply, as in the few studies on economy-wide impacts of liberalizing services trade (e.g., Dinh 2012; Verikios and Zhang 2000). The FTAP model is applied as follows.

\subsection{Model Database Preparation}

This chapter uses data mainly from the GTAP 7 Data Base. This dataset provides individual country input-output tables as well as detailed data on bilateral trade, transport, and merchandise trade protection for 113 regions and 57 sectors in 2004 (Narayanan and Walmsley 2008). ${ }^{3}$ The country input-output tables account for the inter-sectoral linkages within regions, while the other data included show economic linkages between regions. For research purposes and given limited data of sector-specific foreign ownership shares in ASEAN, the GTAP 7 database is aggregated into two regions (ASEAN and the Rest of the World) and 32 sectors (for more details see Appendix Table 5A.1). This baseline data retains restrictions on the movement of natural persons in the ASEAN banking industry. This baseline data will be compared with simulated data to see what impact the policy change has.

The GTAP database aggregates banks with other financial intermediaries, so we treat banking services as universal to the entire financial sector. Given the dominance of banks in ASEAN's financial sector, we expect the results will be reliable.

\subsection{Injection of Current Barriers Estimates}

As the GTAP model does not reflect prevailing trade barriers in banking services, we inject the tax equivalent of ASEAN and Rest of the World banking sectors into the model. The tax equivalent is injected into the model as an implicit output tax-the rents from this tax shock flow to the banking sector rather than to the government. For foreign invested firms, a part of this rent is modelled to be taxed before repatriation. The productivity equivalent does not need to be injected into the model at this stage as it is inherent in bank cost structures.

\subsection{Simulation}

The final step is to simulate the effects of removing all restrictions on the movement of natural persons - the mobility of skilled labor across countries in the region. This trade reform is modelled as a reduction in output tax and a gain in technical change in FDI financial institutions as it is applied only to this service provider group. The simulation is conducted in 
two macroeconomic settings: (i) restricted labor mobility (both unskilled and skilled labor) across industries within a country; and (ii) unrestricted skilled labor mobility across industries within a country. In both settings, capital is assumed to be imperfectly mobile between industries within the region and between regions. The model allows for capital accumulation and international borrowing and lending.

\section{DATA USED FOR SIMULATION}

\subsection{Trade Restrictiveness Indexes}

Table 5.1 presents the key data for simulation as generated using the methodology described above. They include trade restrictiveness indexes (TRIs) for establishment and operation for domestic banks and FDI banks in ASEAN before and after each trade reform. The table also shows the corresponding productivity and tax equivalents.

\subsection{Employment Structure before Simulation}

Table 5.2 shows the employment payment structure by industry and sector in ASEAN (before simulation) using the GTAP 7 Data Base. In 2004, all 32 aggregated industries paid employees $\$ 287$ billion-74\% for unskilled

\section{Table 5.1 Key data for simulation}

\begin{tabular}{|c|c|c|c|c|c|c|}
\hline \multirow[t]{2}{*}{ Item } & \multicolumn{2}{|c|}{ Before } & \multicolumn{2}{|c|}{ After } & \multicolumn{2}{|c|}{ Change } \\
\hline & $\begin{array}{c}\text { FDI } \\
\text { banks }\end{array}$ & $\begin{array}{c}\text { Domestic } \\
\text { banks }\end{array}$ & $\begin{array}{c}\text { FDI } \\
\text { banks }\end{array}$ & $\begin{array}{c}\text { Domestic } \\
\text { banks }\end{array}$ & $\begin{array}{c}\text { FDI } \\
\text { banks }\end{array}$ & $\begin{array}{l}\text { Domestic } \\
\text { banks }\end{array}$ \\
\hline $\begin{array}{l}\text { TRI }(0=\text { No restriction, } \\
1=\text { Highest } \\
\text { restriction })\end{array}$ & 0.26 & 0.08 & 0.20 & 0.08 & -0.02 & 0.00 \\
\hline $\begin{array}{l}\text { Productivity equivalent } \\
\text { (\% change) }\end{array}$ & 48.80 & 14.43 & 44.87 & 14.43 & -3.92 & 0.00 \\
\hline $\begin{array}{l}\text { Tax equivalent } \\
(\% \text { change })\end{array}$ & 20.76 & 7.98 & 19.61 & 7.98 & -1.15 & 0.00 \\
\hline
\end{tabular}

Note: $\quad$ FDI $=$ foreign direct investment; TRI $=$ trade restrictiveness index; Productivity equivalent $=$ percentage change in productivity due to higher costs from trade barriers; Tax equivalent $=$ percentage change in price markup from trade barriers - similar to a tax, but with revenue flowing to banks rather than government.

Source: Author's calculation. 
labor. Among sectors, services contributed most (54.7\%), followed by manufacturing $(32.8 \%)$ and agriculture and mining $(12.5 \%)$. Services also accounted for most in skilled labor (75\%). Domestic firms made up 83\% of employee payments, although they comprised $65 \%$ of capital costs. Financial services accounted for $3.2 \%$ of employee payments, or $6 \%$ of the service sector total.

\subsection{Linkages between Financial Services and Other Industries}

As shown in Table 5.3, financial services are inputs for all industries. Its share in others' total costs ranges from $0.3 \%$ to $12.7 \%$. The five industries with the highest share of financial services as inputs are coal, oil and gas mining $(12.7 \%)$; trade $(11.3 \%)$; insurance $(9.6 \%)$; other businesses $(9.6 \%)$; and communication $(9.4 \%)$. The five industries using financial services least are petroleum and coal products $(0.3 \%)$; wearing apparel $(1.6 \%)$; iron, steel and non-ferrous metals $(1.6 \%)$; leather products $(1.6 \%)$; and recreational and other services $(1.8 \%)$.

The five largest customers of the financial industry (measured by share of financial industry output) are trade (16.5\%); other businesses (7.5\%); electronic equipment (7.2\%); chemical, rubber, plastic products $(6.3 \%)$; and food and beverages and tobacco manufacture (4.6\%). The five customers accounting for the least (less than $0.5 \%$ of total industry output) are water; other mining; forestry; petroleum, coal products; and leather products.

\section{RESULTS AND DISCUSSION}

This section first discusses how trade reform would impact industry output under two different macroeconomic settings-restricted skilled and unskilled labor mobility, and unrestricted skilled labor mobility. It then examines changes in (i) industry output prices, (ii) factor prices, (iii) industry employment, and (iv) allocation of increased employment.

\subsection{Projected Output Changes}

Trade reform leads to increased output in both domestic and foreigninvested firms in all industries except financial services, where the expansion is only observed in foreign banks (Table 5.4). Foreign-invested institutions increase output most, while domestic counterparts stall (when both labor types are restricted) or contract (when at least one type increases labor mobility). Specifically, when both types of labor are restricted, output growth in domestic and foreign financial institutions are 
Table 5.2 ASEAN employment payment structure, 2004 (\$ million)

\begin{tabular}{|c|c|c|c|c|c|c|}
\hline \multirow[t]{2}{*}{ Industry/Sector } & \multicolumn{4}{|c|}{ Domestic firms } & \multicolumn{2}{|c|}{ FDI firms } \\
\hline & Unskilled & Skilled & Total & $\begin{array}{l}\text { Share of } \\
\text { total sector } \\
\text { employees } \\
(\%)\end{array}$ & Unskilled & Skilled \\
\hline Agriculture and mining & 33,764 & 1,118 & 34,882 & 97.0 & 849 & 248 \\
\hline Agriculture & 27,077 & 155 & 27,232 & 100.0 & 0 & 0 \\
\hline Forestry & 2,880 & 25 & 2,905 & 100.0 & 0 & 0 \\
\hline Coal, oil, gas mining & 2,635 & 573 & 3,208 & 93.6 & 179 & 39 \\
\hline Other mining & 1,172 & 365 & 1,537 & 63.7 & 669 & 209 \\
\hline Manufacturing & 66,972 & 15,791 & 82,763 & 87.9 & 9,033 & 2,401 \\
\hline $\begin{array}{l}\text { Food and beverages } \\
\text { and tobacco } \\
\text { manufacture }\end{array}$ & 11,103 & 1,781 & 12,884 & 90.1 & 1,215 & 195 \\
\hline Textiles & 4,079 & 701 & 4,780 & 98.6 & 60 & 10 \\
\hline Wearing apparel & 2,786 & 414 & 3,200 & 98.8 & 35 & 5 \\
\hline Leather products & 1,784 & 304 & 2,087 & 96.9 & 56 & 10 \\
\hline Wood products & 3,351 & 459 & 3,810 & 96.8 & 110 & 15 \\
\hline $\begin{array}{l}\text { Paper products, } \\
\text { publishing }\end{array}$ & 1,938 & 592 & 2,530 & 83.6 & 380 & 116 \\
\hline $\begin{array}{l}\text { Petroleum, coal } \\
\text { products }\end{array}$ & 607 & 170 & 777 & 86.8 & 92 & 26 \\
\hline $\begin{array}{l}\text { Chemical, rubber, } \\
\text { plastic products }\end{array}$ & 9,067 & 2,831 & 11,898 & 79.3 & 2,361 & 737 \\
\hline Mineral products nec & 2,156 & 506 & 2,663 & 91.0 & 213 & 50 \\
\hline $\begin{array}{l}\text { Iron, steel, and } \\
\text { non-ferrous metals }\end{array}$ & 1,924 & 459 & 2,383 & 95.0 & 101 & 24 \\
\hline $\begin{array}{l}\text { Fabricated metal } \\
\text { products }\end{array}$ & 2,000 & 532 & 2,532 & 93.2 & 147 & 39 \\
\hline $\begin{array}{l}\text { Motor vehicles and } \\
\text { parts }\end{array}$ & 1,735 & 404 & 2,140 & 57.3 & 1,291 & 301 \\
\hline $\begin{array}{l}\text { Transport equipment } \\
\text { nec }\end{array}$ & 2,155 & 645 & 2,800 & 92.4 & 177 & 53 \\
\hline Electronic equipment & 15,315 & 4,221 & 19,536 & 96.7 & 521 & 143 \\
\hline $\begin{array}{l}\text { Machinery and } \\
\text { equipment nec }\end{array}$ & 4,246 & 1,361 & 5,606 & 68.4 & 1,965 & 630 \\
\hline Manufactures nec & 2,724 & 413 & 3,137 & 89.7 & 311 & 47 \\
\hline Services & 74,684 & 47,188 & 121,872 & 77.5 & 27,471 & 7,961 \\
\hline $\begin{array}{l}\text { Electricity and gas } \\
\text { production and } \\
\text { distribution }\end{array}$ & 2,763 & 1,585 & 4,347 & 98.0 & 57 & 33 \\
\hline Water & 206 & 119 & 325 & 99.3 & 1 & 1 \\
\hline Construction & 12,760 & 2,654 & 15,414 & 96.2 & 506 & 105 \\
\hline Trade & 11,374 & 2,063 & 13,437 & 35.5 & 20,661 & 3,747 \\
\hline Air, land transport & 9,365 & 2,459 & 11,825 & 98.3 & 163 & 43 \\
\hline Water transport & 1,605 & 474 & 2,079 & 97.7 & 38 & 11 \\
\hline
\end{tabular}




\begin{tabular}{|c|c|c|c|c|c|c|c|}
\hline \multirow[b]{2}{*}{ Total } & \multirow[b]{2}{*}{$\begin{array}{c}\text { Share of } \\
\text { total sector } \\
\text { employees } \\
(\%)\end{array}$} & \multicolumn{6}{|c|}{ ASEAN Total } \\
\hline & & Unskilled & $\begin{array}{c}\text { Share of } \\
\text { total sector } \\
\text { employees } \\
(\%)\end{array}$ & Skilled & $\begin{array}{c}\text { Share of } \\
\text { total sector } \\
\text { employees } \\
(\%)\end{array}$ & $\begin{array}{l}\text { Total } \\
\text { emp. }\end{array}$ & $\begin{array}{l}\% \text { of } \\
\text { total } \\
\text { emp. }\end{array}$ \\
\hline 1,097 & 3.0 & 34,613 & 96.2 & 1,366 & 3.8 & 35,979 & 12.5 \\
\hline 0 & 0.0 & 27,077 & 99.4 & 155 & 0.6 & 27,233 & 9.5 \\
\hline 0 & 0.0 & 2,880 & 99.1 & 25 & 0.9 & 2,905 & 1.0 \\
\hline 218 & 6.4 & 2,814 & 82.1 & 612 & 17.9 & 3,426 & 1.2 \\
\hline 878 & 36.3 & 1,841 & 76.2 & 574 & 23.8 & 2,415 & 0.8 \\
\hline 11,434 & 12.1 & 76,005 & 80.7 & 18,192 & 19.3 & 94,197 & 32.8 \\
\hline 1,410 & 9.9 & 12,318 & 86.2 & 1,976 & 13.8 & 14,294 & 5.0 \\
\hline 70 & 1.4 & 4,139 & 85.3 & 711 & 14.7 & 4,850 & 1.7 \\
\hline 40 & 1.2 & 2,821 & 87.1 & 419 & 12.9 & 3,240 & 1.1 \\
\hline 66 & 3.1 & 1,840 & 85.4 & 313 & 14.6 & 2,153 & 0.7 \\
\hline 125 & 3.2 & 3,461 & 88.0 & 474 & 12.0 & 3,935 & 1.4 \\
\hline 497 & 16.4 & 2,318 & 76.6 & 708 & 23.4 & 3,026 & 1.1 \\
\hline 118 & 13.2 & 699 & 78.1 & 196 & 21.9 & 894 & 0.3 \\
\hline 3,098 & 20.7 & 11,428 & 76.2 & 3,568 & 23.8 & 14,996 & 5.2 \\
\hline 263 & 9.0 & 2,369 & 81.0 & 556 & 19.0 & 2,925 & 1.0 \\
\hline 125 & 5.0 & 2,025 & 80.7 & 483 & 19.3 & 2,508 & 0.9 \\
\hline 186 & 6.8 & 2,147 & 79.0 & 571 & 21.0 & 2,718 & 0.9 \\
\hline 1,591 & 42.7 & 3,026 & 81.1 & 705 & 18.9 & 3,731 & 1.3 \\
\hline 229 & 7.6 & 2,332 & 77.0 & 697 & 23.0 & 3,029 & 1.1 \\
\hline 664 & 3.3 & 15,836 & 78.4 & 4,364 & 21.6 & 20,200 & 7.0 \\
\hline 2,595 & 31.6 & 6,211 & 75.7 & 1,991 & 24.3 & 8,202 & 2.9 \\
\hline 359 & 10.3 & 3,036 & 86.8 & 460 & 13.2 & 3,495 & 1.2 \\
\hline 35,431 & 22.5 & 102,155 & 64.9 & 55,149 & 35.1 & 157,304 & 54.7 \\
\hline 90 & 2.0 & 2,820 & 63.5 & 1,618 & 36.5 & 4,437 & 1.5 \\
\hline 2 & 0.7 & 208 & 63.4 & 120 & 36.6 & 327 & 0.1 \\
\hline 611 & 3.8 & 13,266 & 82.8 & 2,759 & 17.2 & 16,025 & 5.6 \\
\hline 24,409 & 64.5 & 32,035 & 84.6 & 5,810 & 15.4 & 37,846 & 13.2 \\
\hline 206 & 1.7 & 9,528 & 79.2 & 2,502 & 20.8 & 12,031 & 4.2 \\
\hline 49 & 2.3 & 1,643 & 77.2 & 485 & 22.8 & 2,128 & 0.7 \\
\hline
\end{tabular}


Table 5.2 (continued)

\begin{tabular}{|c|c|c|c|c|c|c|}
\hline \multirow[t]{2}{*}{ Industry/Sector } & \multicolumn{4}{|c|}{ Domestic firms } & \multicolumn{2}{|c|}{ FDI firms } \\
\hline & Unskilled & Skilled & Total & $\begin{array}{l}\text { Share of } \\
\text { total sector } \\
\text { employees } \\
(\%)\end{array}$ & Unskilled & Skilled \\
\hline Communication & 1,792 & 1,193 & 2,985 & 89.5 & 211 & 140 \\
\hline Financial services nec & 3,469 & 2,374 & 5,843 & 63.5 & 1,997 & 1,367 \\
\hline Insurance & 314 & 209 & 523 & 25.7 & 908 & 604 \\
\hline Other business services & 6,260 & 3,988 & 10,248 & 68.7 & 2,854 & 1,818 \\
\hline $\begin{array}{l}\text { Recreational and other } \\
\text { services }\end{array}$ & 4,996 & 2,995 & 7,991 & 99.7 & 14 & 8 \\
\hline $\begin{array}{l}\text { Public administration } \\
\text { and defense, } \\
\text { education, health }\end{array}$ & 19,779 & 27,076 & 46,856 & 99.7 & 61 & 83 \\
\hline Total & 175,420 & 64,098 & 239,518 & 83.3 & 37,353 & 10,609 \\
\hline
\end{tabular}

Note: $\quad$ ASEAN $=$ Association of Southeast Asian Nations; nec $=$ not elsewhere classified.

Source: Author's calculation from GTAP 7 Data Base.

$-0.003 \%$ and $5.66 \%$, respectively. When only unskilled labor is restricted, the corresponding figures are $-0.77 \%$ and $8.4 \%$.

This result can be explained by the fact that trade reform in foreigninvested financial institutions reduces output tax and creates productivity gains in these firms. A decline in output tax on foreign-invested financial services reduces their supply price, which is equivalent to the expansion in supply. A productivity gain leads to reduced production costs, which also raises supply. Both shocks expand FDI financial institution output and thus reduce their market price, making their services less costly than domestic counterparts. Financial services from FDI institutions thus substitute those from domestic firms, creating a crowding-out effect (an expansion of FDI institutions comes at the expense of their counterparts). The expansion of FDI institutions raises their demand for labor. When labor mobility is restricted, any increased demand for labor must be met by an increase in labor supply. If labor can move freely, at least part of the increased demand can be filled by attracting labor from domestic institutions - which further increases the crowding-out effects on domestic counterparts.

Expanding FDI financial firms also triggers an expansion of other industries through spill-over effects. As shown in Table 5.3, the financial industry uses the output of all other sectors as inputs - and all industries use financial services as an input in production. The expansion of other 


\begin{tabular}{|c|c|c|c|c|c|c|c|}
\hline \multirow[b]{2}{*}{ Total } & \multirow[b]{2}{*}{$\begin{array}{c}\text { Share of } \\
\text { total sector } \\
\text { employees } \\
(\%)\end{array}$} & \multicolumn{6}{|c|}{ ASEAN Total } \\
\hline & & Unskilled & $\begin{array}{c}\text { Share of } \\
\text { total sector } \\
\text { employees } \\
(\%)\end{array}$ & Skilled & $\begin{array}{c}\text { Share of } \\
\text { total sector } \\
\text { employees } \\
(\%)\end{array}$ & $\begin{array}{l}\text { Total } \\
\text { emp. }\end{array}$ & $\begin{array}{l}\% \text { of } \\
\text { total } \\
\text { emp. }\end{array}$ \\
\hline 351 & 10.5 & 2,003 & 60.0 & 1,333 & 40.0 & 3,336 & 1.2 \\
\hline 3,364 & 36.5 & 5,466 & 59.4 & 3,741 & 40.6 & 9,207 & 3.2 \\
\hline 1,513 & 74.3 & 1,222 & 60.0 & 813 & 40.0 & 2,035 & 0.7 \\
\hline 4,672 & 31.3 & 9,114 & 61.1 & 5,806 & 38.9 & 14,920 & 5.2 \\
\hline 22 & 0.3 & 5,010 & 62.5 & 3,003 & 37.5 & 8,013 & 2.8 \\
\hline 143 & 0.3 & 19,840 & 42.2 & 27,159 & 57.8 & 46,999 & 16.3 \\
\hline 47,962 & 16.7 & 212,773 & 74.0 & 73,341 & 26.0 & 287,480 & 100 \\
\hline
\end{tabular}

industries thus occurs in two ways: (i) FDI financial firms will increase their demand for other industry outputs; and (ii) lower market prices for financial services will reduce production costs for industries using financial services as inputs. When both types of labor are restricted, the industry output growth ranges from $0.06 \%$ to $0.48 \%$. The industries with the highest growth are public administration, defense and health; recreational and other services; and transport equipment not elsewhere classified (nec). The least growth occurs in coal, oil, gas mining. When only unskilled labor is restricted, the output growth ranges from $0.05 \%$ to $0.43 \%$. Again, the most expansion is in public administration, defense and health; recreational and other services; and transport equipment nec. The least growth occurs in coal, oil, gas mining.

\subsection{Projected Output Price Changes}

In all settings, output prices in financial services decline most in both domestic and foreign-invested institutions (Table 5.5). The price fall of FDI institutions comes from their output expansion, while domestic counterpart prices fall from their contraction due to the crowding-out effect. When both unskilled and skilled labor types lack mobility between industries (and also countries) in the region, the price of financial services falls by $0.94 \%$ for domestic institutions and $1.49 \%$ for FDI counterparts. When only skilled labor can move, the reduction is even higher- $-1.09 \%$ and $1.96 \%$, respectively. 
Table 5.3 Linkages between financial services and other industries in ASEAN, 2004

\begin{tabular}{|c|c|c|c|c|c|c|}
\hline \multirow[t]{2}{*}{ Industry/Sector } & \multicolumn{3}{|c|}{$\begin{array}{c}\text { Share of financial services } \\
\text { in production cost }\end{array}$} & \multicolumn{3}{|c|}{$\begin{array}{l}\text { Share of total financial } \\
\text { service output }\end{array}$} \\
\hline & $\begin{array}{l}\text { Domestic } \\
\text { firms }\end{array}$ & $\begin{array}{l}\text { FDI } \\
\text { firms }\end{array}$ & $\begin{array}{l}\text { All } \\
\text { firms }\end{array}$ & $\begin{array}{l}\text { Domestic } \\
\text { firms }\end{array}$ & $\begin{array}{l}\text { FDI } \\
\text { firms }\end{array}$ & $\begin{array}{c}\text { All } \\
\text { firms }\end{array}$ \\
\hline \multicolumn{7}{|l|}{ Agriculture and mining } \\
\hline Agriculture & 2.7 & 2.7 & 2.7 & 2.4 & 0.0 & 1.7 \\
\hline Forestry & 5.1 & 5.1 & 5.1 & 0.3 & 0.0 & 0.2 \\
\hline Coal, oil, gas mining & 12.7 & 12.7 & 12.7 & 2.9 & 0.5 & 2.3 \\
\hline Other mining & 2.2 & 2.2 & 2.2 & 0.2 & 0.3 & 0.2 \\
\hline \multicolumn{7}{|l|}{ Manufacturing } \\
\hline $\begin{array}{c}\text { Food and beverages and } \\
\text { tobacco manufacture }\end{array}$ & 2.1 & 2.1 & 2.1 & 5.7 & 1.7 & 4.6 \\
\hline Textiles & 2.4 & 2.4 & 2.4 & 2.2 & 0.1 & 1.6 \\
\hline Wearing apparel & 1.6 & 1.6 & 1.6 & 1.0 & 0.0 & 0.7 \\
\hline Leather products & 1.6 & 1.6 & 1.6 & 0.6 & 0.1 & 0.5 \\
\hline Wood products & 5.0 & 5.0 & 5.0 & 2.3 & 0.2 & 1.7 \\
\hline $\begin{array}{l}\text { Paper products, } \\
\text { publishing }\end{array}$ & 2.7 & 2.7 & 2.7 & 1.1 & 0.6 & 1.0 \\
\hline Petroleum, coal products & 0.3 & 0.3 & 0.3 & 0.4 & 0.2 & 0.4 \\
\hline $\begin{array}{l}\text { Chemical, rubber, plastic } \\
\text { products }\end{array}$ & 3.2 & 3.2 & 3.2 & 6.9 & 4.8 & 6.3 \\
\hline Mineral products nec & 3.2 & 3.2 & 3.2 & 1.1 & 0.3 & 0.9 \\
\hline $\begin{array}{l}\text { Iron, steel, and } \\
\text { non-ferrous metals }\end{array}$ & 1.6 & 1.6 & 1.6 & 1.1 & 0.2 & 0.8 \\
\hline $\begin{array}{l}\text { Fabricated metal } \\
\text { products }\end{array}$ & 2.2 & 2.2 & 2.2 & 1.2 & 0.2 & 0.9 \\
\hline Motor vehicles and parts & 2.3 & 2.3 & 2.3 & 1.0 & 2.0 & 1.3 \\
\hline Transport equipment nec & 2.3 & 2.3 & 2.3 & 0.7 & 0.2 & 0.5 \\
\hline Electronic equipment & 1.9 & 1.9 & 1.9 & 9.6 & 0.9 & 7.2 \\
\hline $\begin{array}{l}\text { Machinery and } \\
\text { equipment nec }\end{array}$ & 2.1 & 2.1 & 2.1 & 2.4 & 3.1 & 2.6 \\
\hline $\begin{array}{l}\text { Manufactures nec } \\
\text { Services }\end{array}$ & 3.4 & 3.4 & 3.4 & 2.1 & 0.7 & 1.7 \\
\hline $\begin{array}{l}\text { Electricity and gas } \\
\text { production and } \\
\text { distribution }\end{array}$ & 2.4 & 2.4 & 2.4 & 1.7 & 0.1 & 1.3 \\
\hline Water & 3.5 & 3.5 & 3.5 & 0.1 & 0.0 & 0.1 \\
\hline Construction & 2.6 & 2.6 & 2.6 & 4.6 & 0.5 & 3.5 \\
\hline Trade & 11.3 & 11.3 & 11.3 & 8.0 & 39.4 & 16.5 \\
\hline Air, land transport & 2.8 & 2.8 & 2.8 & 4.4 & 0.2 & 3.2 \\
\hline Water transport & 2.6 & 2.6 & 2.6 & 1.6 & 0.1 & 1.2 \\
\hline
\end{tabular}


Table 5.3 (continued)

\begin{tabular}{|c|c|c|c|c|c|c|}
\hline \multirow[t]{2}{*}{ Industry/Sector } & \multicolumn{3}{|c|}{$\begin{array}{l}\text { Share of financial services } \\
\text { in production cost }\end{array}$} & \multicolumn{3}{|c|}{$\begin{array}{l}\text { Share of total financial } \\
\text { service output }\end{array}$} \\
\hline & $\begin{array}{l}\text { Domestic } \\
\text { firms }\end{array}$ & $\begin{array}{l}\text { FDI } \\
\text { firms }\end{array}$ & $\begin{array}{l}\text { All } \\
\text { firms }\end{array}$ & $\begin{array}{l}\text { Domestic } \\
\text { firms }\end{array}$ & $\begin{array}{l}\text { FDI } \\
\text { firms }\end{array}$ & $\begin{array}{l}\text { All } \\
\text { firms }\end{array}$ \\
\hline Communication & 9.4 & 9.4 & 9.4 & 1.2 & 0.4 & 0.9 \\
\hline Financial services nec & 50.8 & 50.8 & 50.8 & 21.6 & 31.1 & 24.2 \\
\hline Insurance & 9.6 & 9.6 & 9.6 & 0.4 & 3.5 & 1.3 \\
\hline Other business services & 9.6 & 9.6 & 9.6 & 7.1 & 8.7 & 7.5 \\
\hline $\begin{array}{l}\text { Recreational and other } \\
\text { services }\end{array}$ & 1.8 & 1.8 & 1.8 & 1.1 & 0.0 & 0.8 \\
\hline $\begin{array}{l}\text { Public administration } \\
\text { and defense, } \\
\text { education, health }\end{array}$ & 2.6 & 2.6 & 2.6 & 3.0 & 0.0 & 2.2 \\
\hline
\end{tabular}

Note: $\quad$ ASEAN $=$ Association of Southeast Asian Nations; FDI $=$ foreign direct investment; nec $=$ not elsewhere classified.

Source: GTAP 7 Data Base.

Trade reform also impacts the output prices of other industries through both the industry's supply and demand. As mentioned above, on the one hand, trade reform raises the demand for other industries' output, which in turn increases their market price. On the other hand, trade reform increases the industry's supply, which reduces the supply price. If the expansion in supply is big enough to outweigh the rise in demand, then the market price will fall, and vice versa. In our simulations, a fall in market price is observed in 20 industries (when movements in both labor types are restricted) and 21 industries (when only unskilled labor is restricted).

\subsection{Projected Wage and Capital Price Changes}

In all simulations, changes in factor prices are the same for domestic and FDI firms within each industry (except in financial services), as they share the same cost structure and are affected equally by trade reform. As discussed, in financial services, trade reform creates a crowding-out effect on domestic firms - price changes are expected to be different between domestic and FDI players when use of factor endowments is restricted.

The change in factor price is caused by two competing effects. The expansion raises the demand for endowments, thereby raising the factor price. With endogenous endowments (total variable labor supply and 
Table 5.4 Change in industry output (\%)

\begin{tabular}{|c|c|c|c|c|}
\hline \multirow[t]{2}{*}{ Industry/Sector } & \multicolumn{2}{|c|}{$\begin{array}{c}\text { Restricted labor } \\
\text { mobility }\end{array}$} & \multicolumn{2}{|c|}{$\begin{array}{l}\text { Unrestricted skilled } \\
\text { labor mobility }\end{array}$} \\
\hline & $\begin{array}{l}\text { Domestic } \\
\text { firms }\end{array}$ & $\begin{array}{l}\text { FDI } \\
\text { firms }\end{array}$ & $\begin{array}{l}\text { Domestic } \\
\text { firms }\end{array}$ & $\begin{array}{l}\text { FDI } \\
\text { firms }\end{array}$ \\
\hline \multicolumn{5}{|l|}{ Agriculture and mining } \\
\hline Agriculture & 0.17 & 0.17 & 0.18 & 0.18 \\
\hline Forestry & 0.21 & 0.21 & 0.22 & 0.22 \\
\hline Coal, oil, gas mining & 0.06 & 0.06 & 0.05 & 0.05 \\
\hline Other mining & 0.19 & 0.19 & 0.16 & 0.16 \\
\hline \multicolumn{5}{|l|}{ Manufacturing } \\
\hline $\begin{array}{l}\text { Food and beverages and tobacco } \\
\text { manufacture }\end{array}$ & 0.21 & 0.21 & 0.22 & 0.21 \\
\hline Textiles & 0.21 & 0.21 & 0.22 & 0.22 \\
\hline Wearing apparel & 0.21 & 0.21 & 0.21 & 0.21 \\
\hline Leather products & 0.21 & 0.21 & 0.21 & 0.21 \\
\hline Wood products & 0.23 & 0.23 & 0.26 & 0.26 \\
\hline Paper products, publishing & 0.21 & 0.21 & 0.21 & 0.21 \\
\hline Petroleum, coal products & 0.17 & 0.17 & 0.19 & 0.18 \\
\hline Chemical, rubber, plastic products & 0.23 & 0.23 & 0.25 & 0.25 \\
\hline Mineral products nec & 0.21 & 0.21 & 0.21 & 0.20 \\
\hline Iron, steel, and non-ferrous metals & 0.20 & 0.20 & 0.19 & 0.19 \\
\hline Fabricated metal products & 0.24 & 0.24 & 0.25 & 0.25 \\
\hline Motor vehicles and parts & 0.22 & 0.22 & 0.23 & 0.23 \\
\hline Transport equipment nec & 0.26 & 0.26 & 0.25 & 0.25 \\
\hline Electronic equipment & 0.20 & 0.20 & 0.21 & 0.21 \\
\hline Machinery and equipment nec & 0.24 & 0.24 & 0.24 & 0.24 \\
\hline Manufactures nec & 0.24 & 0.24 & 0.27 & 0.27 \\
\hline \multicolumn{5}{|l|}{ Services } \\
\hline $\begin{array}{l}\text { Electricity and gas production and } \\
\text { distribution }\end{array}$ & 0.21 & 0.21 & 0.24 & 0.24 \\
\hline Water & 0.14 & 0.13 & 0.14 & 0.14 \\
\hline Construction & 0.21 & 0.21 & 0.18 & 0.17 \\
\hline Trade & 0.24 & 0.24 & 0.28 & 0.27 \\
\hline Air, land transport & 0.21 & 0.21 & 0.21 & 0.21 \\
\hline Water transport & 0.21 & 0.21 & 0.22 & 0.22 \\
\hline Communication & 0.17 & 0.16 & 0.15 & 0.15 \\
\hline Financial services nec & 0.00 & 5.66 & -0.77 & 8.40 \\
\hline Insurance & 0.24 & 0.24 & 0.29 & 0.29 \\
\hline Other business services & 0.14 & 0.14 & 0.13 & 0.13 \\
\hline Recreational and other services & 0.31 & 0.31 & 0.29 & 0.29 \\
\hline $\begin{array}{l}\text { Public administration and defense, } \\
\text { education, health }\end{array}$ & 0.48 & 0.48 & 0.43 & 0.43 \\
\hline
\end{tabular}


Table 5.4 (continued)

\begin{abstract}
Notes:
FDI $=$ foreign direct investment; nec $=$ not elsewhere classified.

The numbers in the table should be read as a percentage. For example, under the assumption of restricted labor mobility between industries, the removal of restrictions on the movement of natural persons would increase the output of agriculture by $0.17 \%$.
\end{abstract}

Source: Author's simulation using GTAP 7 Data Base.

accumulating capital in this case), excessive demand can be relaxed by a higher endowment supply in the long run, thereby reducing factor prices. When endowments move restrictedly from one industry to another, excessive demand for endowments can only be met by an increase in supply. If the expansion in total supply of endowments is big enough to outweigh the increase in demand, a fall in factor price would occur-or a rise otherwise. As a result, different changes in factor prices can be observed across industries. When endowments are mobile, excessive factor demand can also be met by attracting factors from other industries until the endowment market clears. Consequently, a uniform change in factor price can be observed across industries.

\title{
6.3.1 Restricted labor mobility (Table 5.6a)
}

When both types of labor are restricted and capital is less than perfectly mobile between industries, the price of these endowments changes differently across industries. Except in financial services, a fall in labor price occurs in ten industries (for unskilled labor) and 26 industries (for skilled labor). In domestic financial firms, wages fall $1.75 \%$ for unskilled labor and $1.94 \%$ for skilled labor-labor demand falls due to the drop in production. By contrast, in FDI counterparts, wages increase $8.76 \%$ for unskilled labor and $8.55 \%$ for skilled labor-as increased labor demand outweighs increased labor supply. Except in construction and domestic financial institutions, industries face higher prices for capital (ranging from $0.17 \%$ to $0.83 \%$ ) as well as a higher relative price of capital to labor. By contrast, construction and domestic financial institutions see a fall in capital costs and lower relative price of capital to labor.

\subsubsection{Unrestricted skilled labor mobility (Table 5.6b)}

As unskilled labor mobility is restricted, price changes vary between industries. Except for financial services, nine other industries see lower capital costs. In financial services, the price of capital falls by $2.72 \%$ in domestic institutions, while it increases by $10.8 \%$ in FDI counterparts-their 
Table 5.5 Change in market price of industry output (\%)

\begin{tabular}{|c|c|c|c|c|}
\hline \multirow[t]{2}{*}{ Industry/Sector } & \multicolumn{2}{|c|}{$\begin{array}{c}\text { Restricted labor } \\
\text { mobility }\end{array}$} & \multicolumn{2}{|c|}{$\begin{array}{l}\text { Unrestricted skilled } \\
\text { labor mobility }\end{array}$} \\
\hline & $\begin{array}{l}\text { Domestic } \\
\text { firms }\end{array}$ & $\begin{array}{c}\text { FDI } \\
\text { firms }\end{array}$ & $\begin{array}{l}\text { Domestic } \\
\text { firms }\end{array}$ & $\begin{array}{l}\text { FDI } \\
\text { firms }\end{array}$ \\
\hline \multicolumn{5}{|l|}{ Agriculture and mining } \\
\hline Agriculture & 0.04 & 0.04 & 0.04 & 0.04 \\
\hline Forestry & -0.05 & -0.05 & -0.05 & -0.05 \\
\hline Coal, oil, gas mining & 0.03 & 0.03 & 0.03 & 0.03 \\
\hline Other mining & -0.01 & -0.01 & 0.00 & 0.00 \\
\hline \multicolumn{5}{|l|}{ Manufacturing } \\
\hline $\begin{array}{l}\text { Food and beverages and tobacco } \\
\text { manufacture }\end{array}$ & -0.01 & -0.01 & -0.01 & -0.01 \\
\hline Textiles & -0.01 & -0.01 & -0.01 & -0.01 \\
\hline Wearing apparel & -0.02 & -0.02 & -0.02 & -0.02 \\
\hline Leather products & -0.03 & -0.03 & -0.02 & -0.02 \\
\hline Wood products & -0.06 & -0.06 & -0.05 & -0.05 \\
\hline Paper products, publishing & 0.00 & 0.00 & 0.00 & 0.00 \\
\hline Petroleum, coal products & 0.04 & 0.04 & 0.04 & 0.04 \\
\hline Chemical, rubber, plastic products & -0.02 & -0.02 & -0.02 & -0.02 \\
\hline Mineral products nec & -0.02 & -0.02 & -0.02 & -0.02 \\
\hline Iron, steel, and non-ferrous metals & 0.00 & 0.00 & -0.01 & -0.01 \\
\hline Fabricated metal products & -0.01 & -0.01 & -0.02 & -0.02 \\
\hline Motor vehicles and parts & 0.00 & 0.00 & -0.01 & -0.01 \\
\hline Transport equipment nec & 0.00 & 0.00 & -0.01 & -0.01 \\
\hline Electronic equipment & -0.05 & -0.05 & -0.03 & -0.03 \\
\hline Machinery and equipment nec & -0.01 & -0.01 & -0.02 & -0.02 \\
\hline Manufactures nec & -0.01 & -0.01 & -0.02 & -0.02 \\
\hline \multicolumn{5}{|l|}{ Services } \\
\hline $\begin{array}{l}\text { Electricity and gas production and } \\
\text { distribution }\end{array}$ & 0.24 & 0.24 & 0.18 & 0.18 \\
\hline Water & 0.17 & 0.17 & 0.19 & 0.19 \\
\hline Construction & -0.21 & -0.21 & -0.12 & -0.12 \\
\hline Trade & 0.03 & 0.03 & 0.01 & 0.01 \\
\hline Air, land transport & -0.01 & -0.01 & -0.01 & -0.01 \\
\hline Water transport & -0.04 & -0.04 & -0.05 & -0.05 \\
\hline Communication & 0.04 & 0.04 & 0.05 & 0.05 \\
\hline Financial services nec & -0.94 & -1.49 & -1.09 & -1.96 \\
\hline Insurance & 0.02 & 0.02 & 0.00 & 0.00 \\
\hline Other business services & 0.05 & 0.05 & 0.05 & 0.05 \\
\hline Recreational and other services & -0.01 & -0.01 & 0.00 & 0.00 \\
\hline $\begin{array}{l}\text { Public administration and defense, } \\
\text { education, health }\end{array}$ & -0.06 & -0.06 & -0.03 & -0.03 \\
\hline
\end{tabular}




\title{
Table 5.5 (continued)
}

\begin{abstract}
Notes:
FDI $=$ foreign direct investment; nec $=$ not elsewhere classified.

The numbers in the table should be read as a percentage. For example, under the assumption of restricted labor mobility between industries, the removal of restrictions on the movement of natural persons would increase the agriculture output of domestic firms by $0.04 \%$.
\end{abstract}

Source: Author's simulation using GTAP 7 Data Base.

demand curve moves in the opposite direction. The price of skilled labor drops $0.03 \%$ uniformly, as skilled labor can move freely between industries and the increased labor supply is above increased labor demand.

The percentage change in the relative price of labor to capital - as measured by the difference in the percentage change in the labor price and that in the capital price - is shown in Table 5.7. Regardless of restrictions on labor mobility across industries, a reduction in the relative price of unskilled labor to capital occurs in only around one-third of the 32 industries, while a drop in the relative price of skilled labor to capital is observed in more than two-thirds of the industries. In other words, the costs of skilled labor become relatively less expensive than capital and unskilled labor if restrictions on the movement of natural persons are removed. Skilled labor becomes more affordable.

\subsection{Projected Employment Growth by Industry (Table 5.8)}

\subsubsection{Restricted labor mobility}

When labor mobility is restricted between industries, any increased demand for labor driven by trade reform can only be met by an increase in labor supply. There is thus a uniform change in employment growth across industries and domestic and FDI firms, including domestic financial institutions - where a drop in output is observed. The growth in employment in domestic financial institutions comes from the relatively less expensive cost of labor as opposed to capital — so the increased labor supply in this group is fully absorbed and replaces capital. Skilled labor grows more than unskilled labor $(0.61 \%$ versus $0.36 \%)$ as the financial sector trade reform is skilled-labor intensive.

\subsubsection{Unrestricted skilled labor mobility}

With unskilled labor restricted between industries, there will be uniform growth in unskilled employment across industries $(0.39 \%)$. But with free skilled labor mobility between industries, increased demand for labor in one 


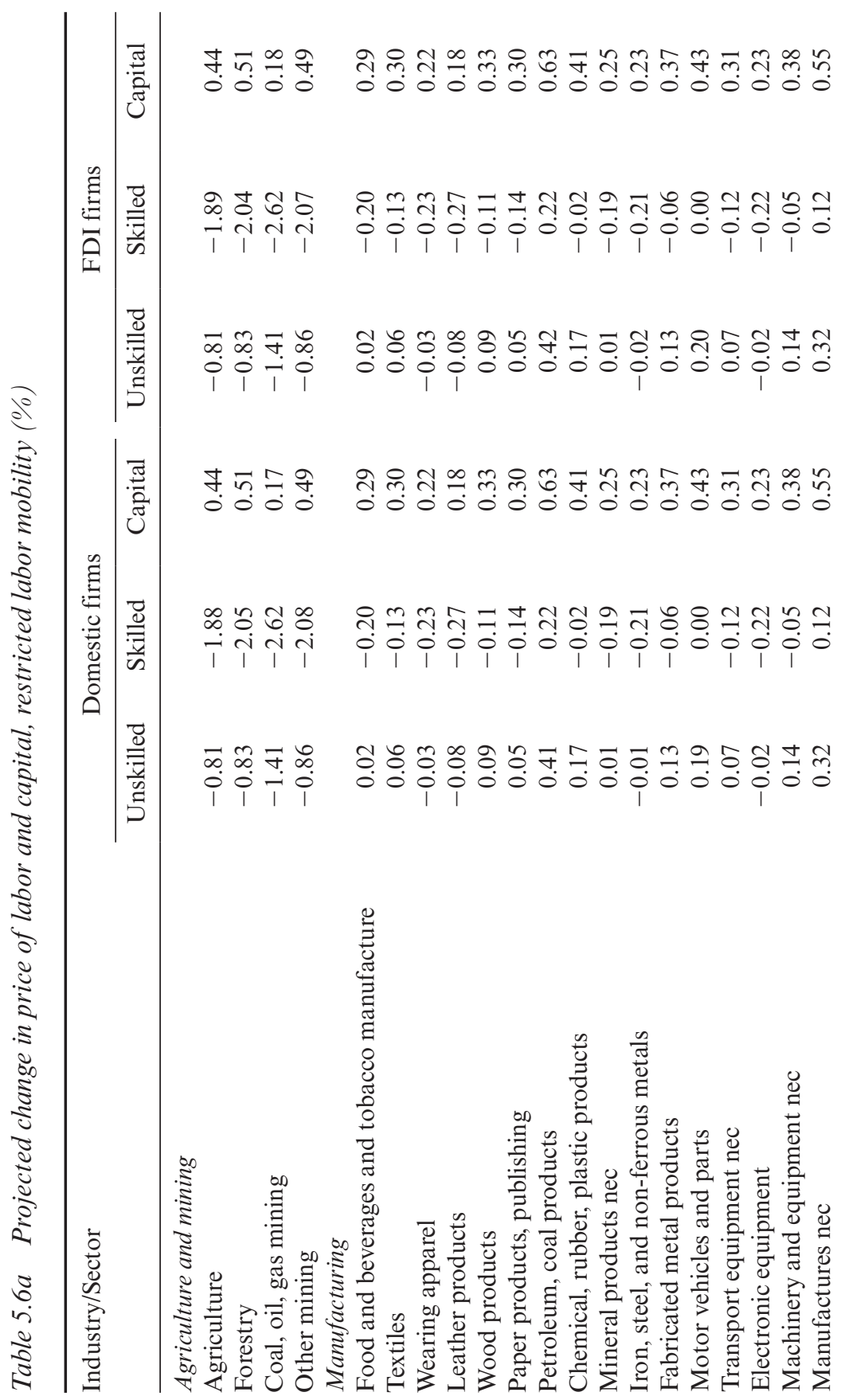




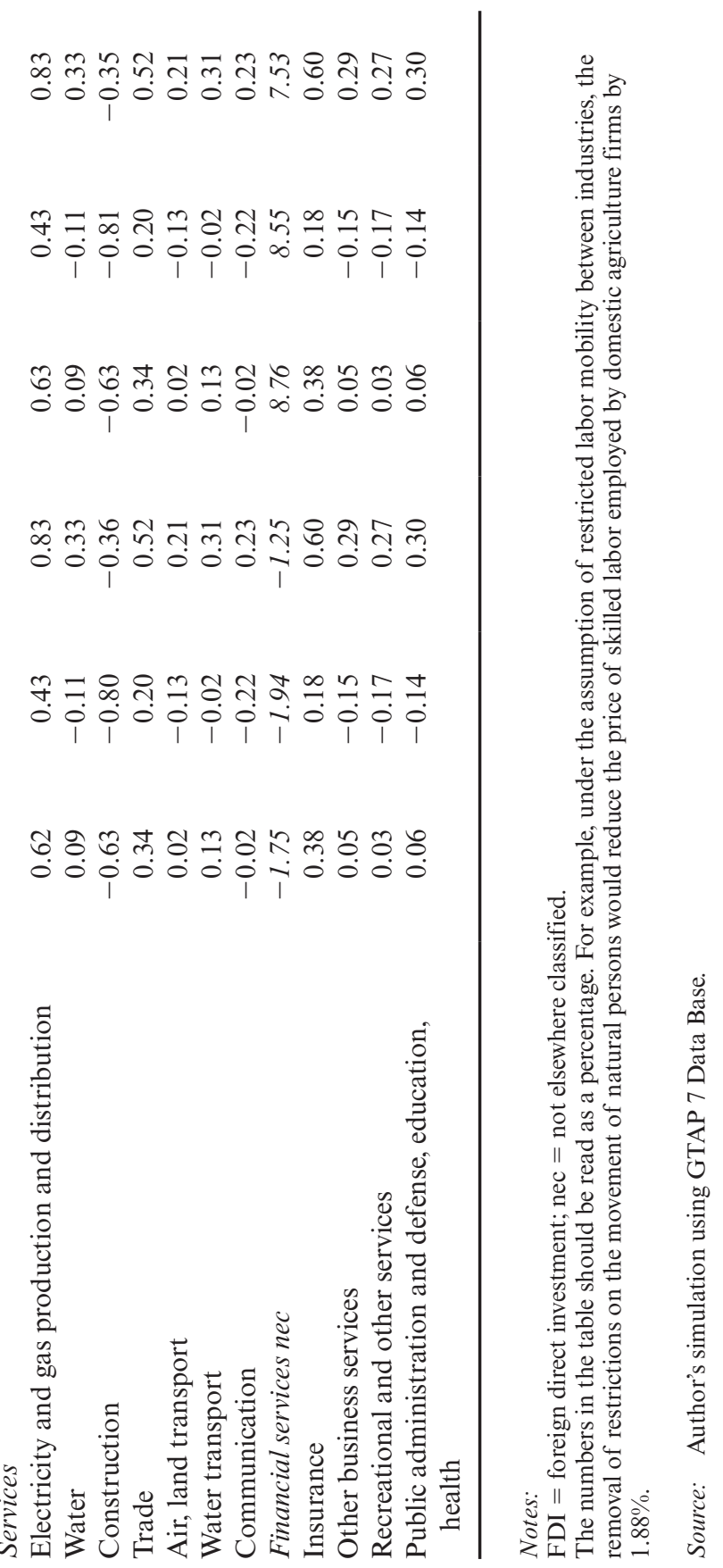




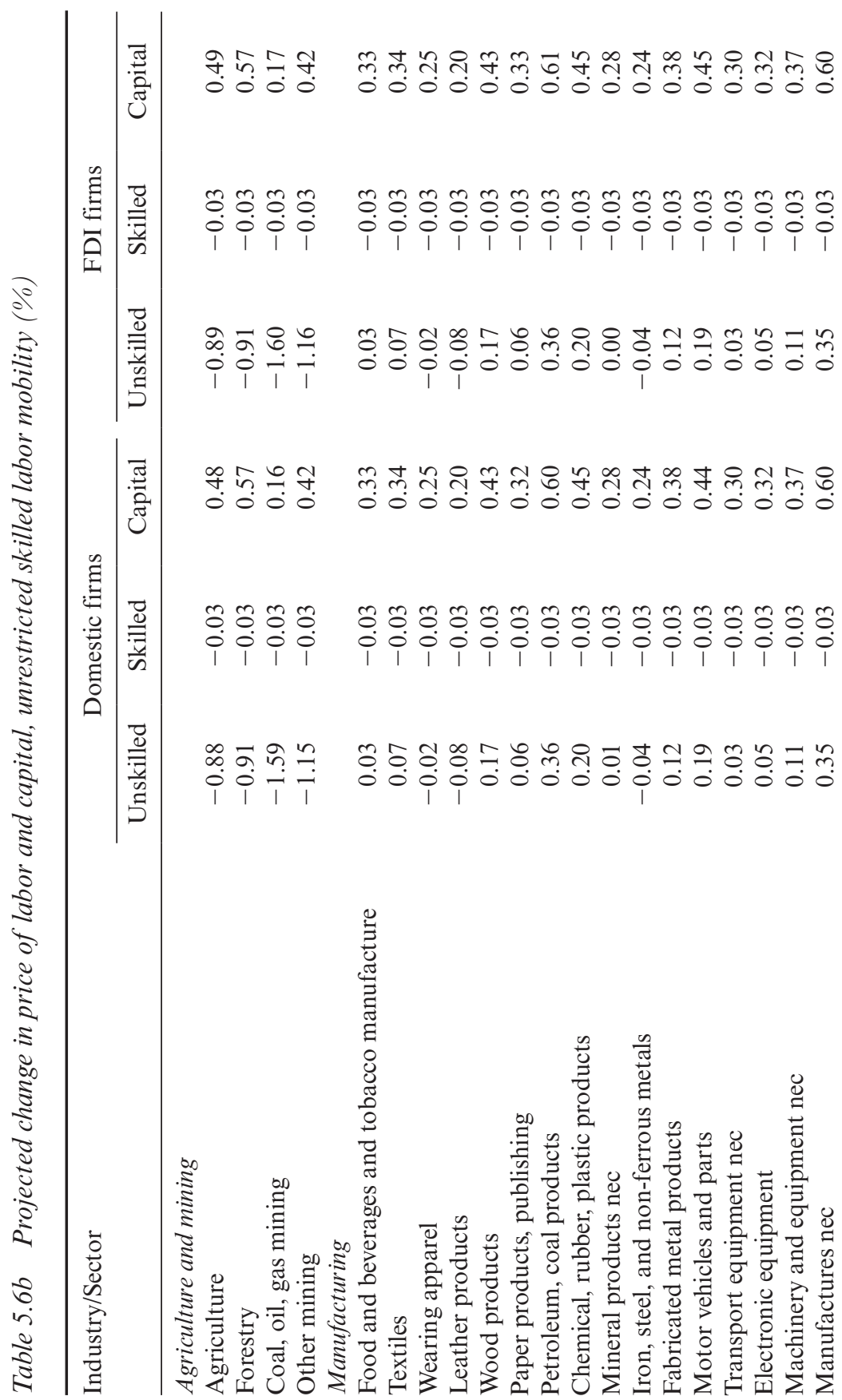




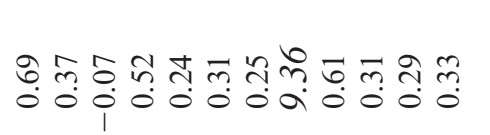

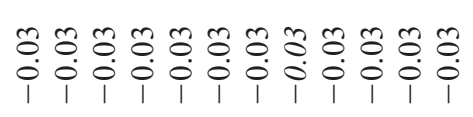

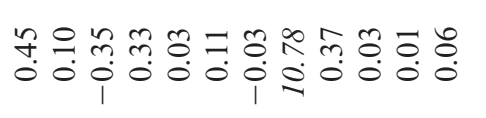

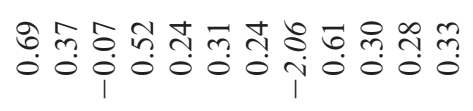

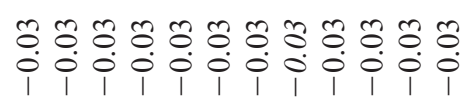

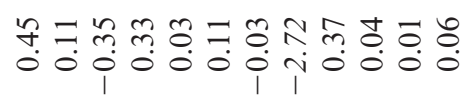
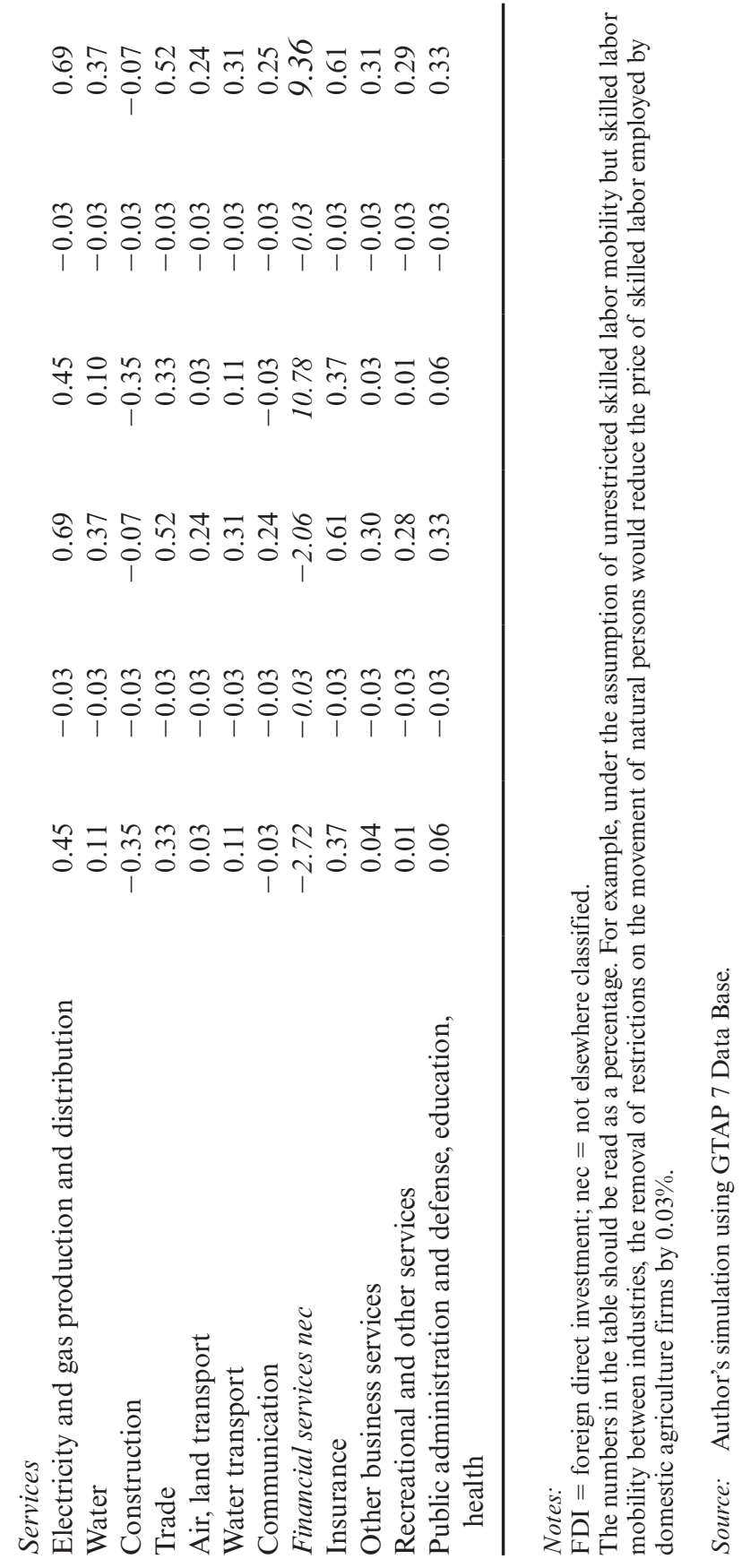


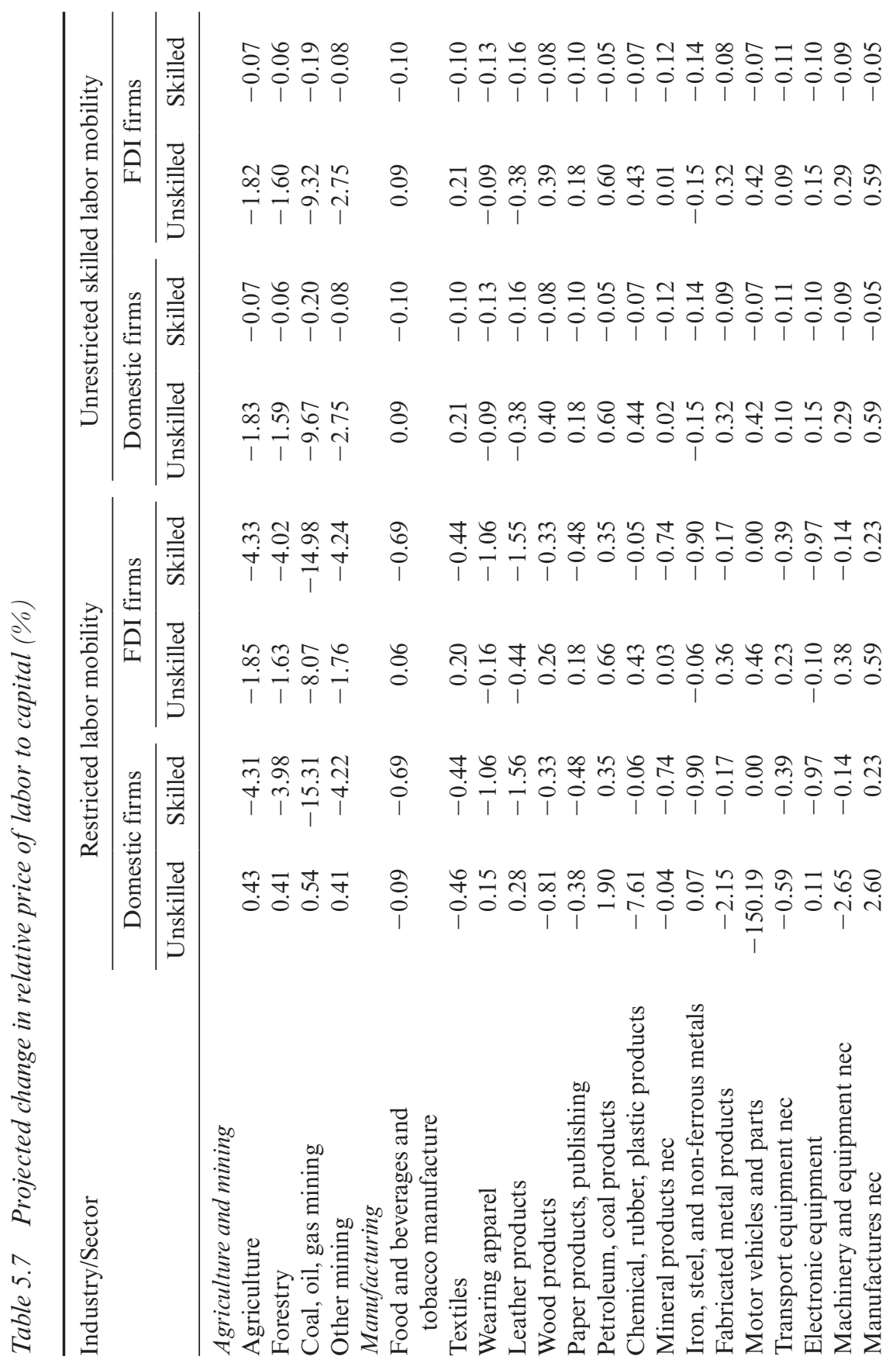


o̊n

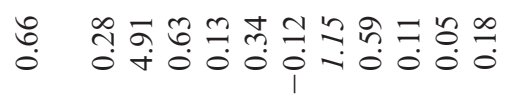

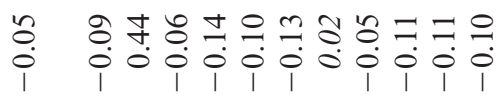

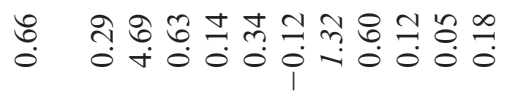

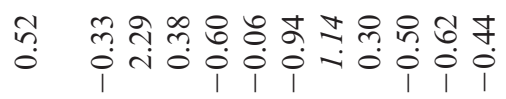

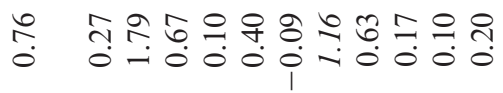

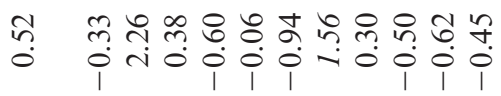

赵

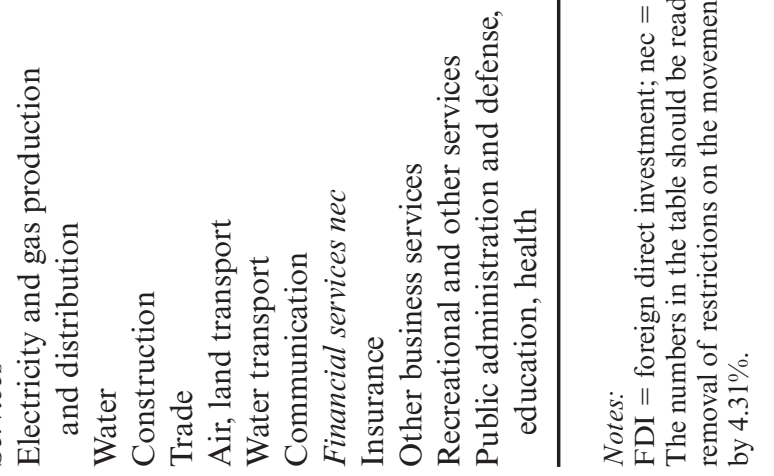

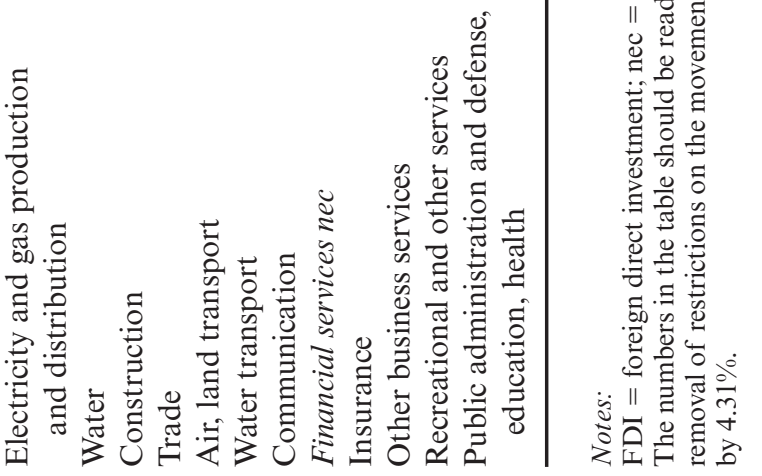

g.

仓ั)

雚

षี.

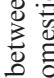

急

ำำ

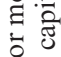

8

횽

畩兽

究

ธี

․ㅡㄹ

言

인

ᄒำ

导

एक

范票

ฮ่ 凶े

卷放

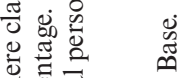

部苛

范

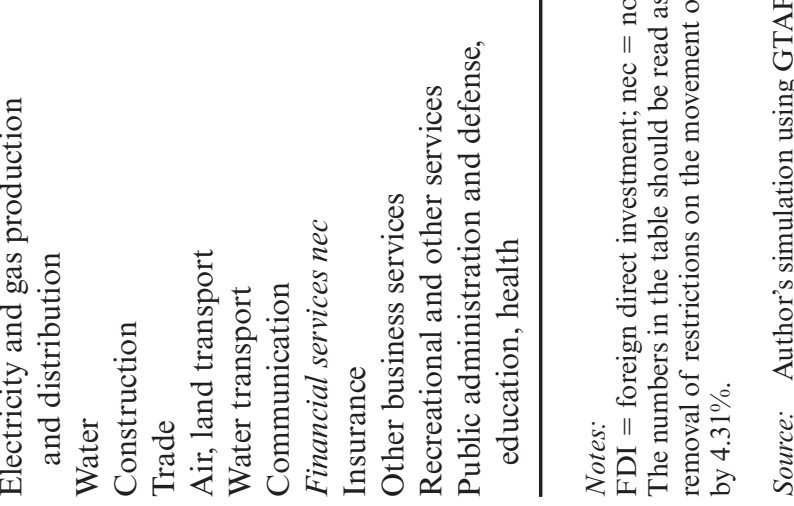

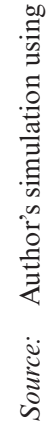




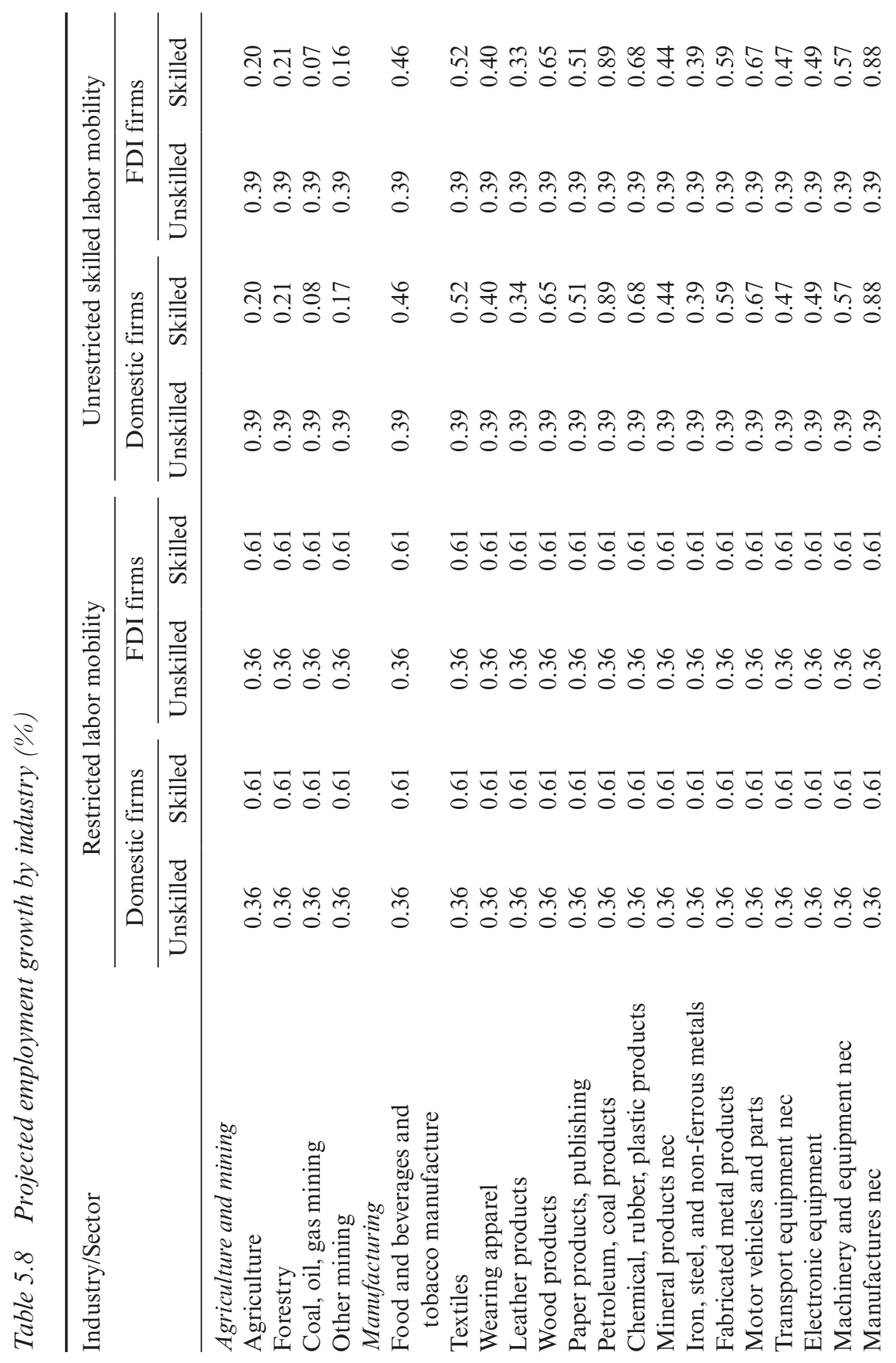




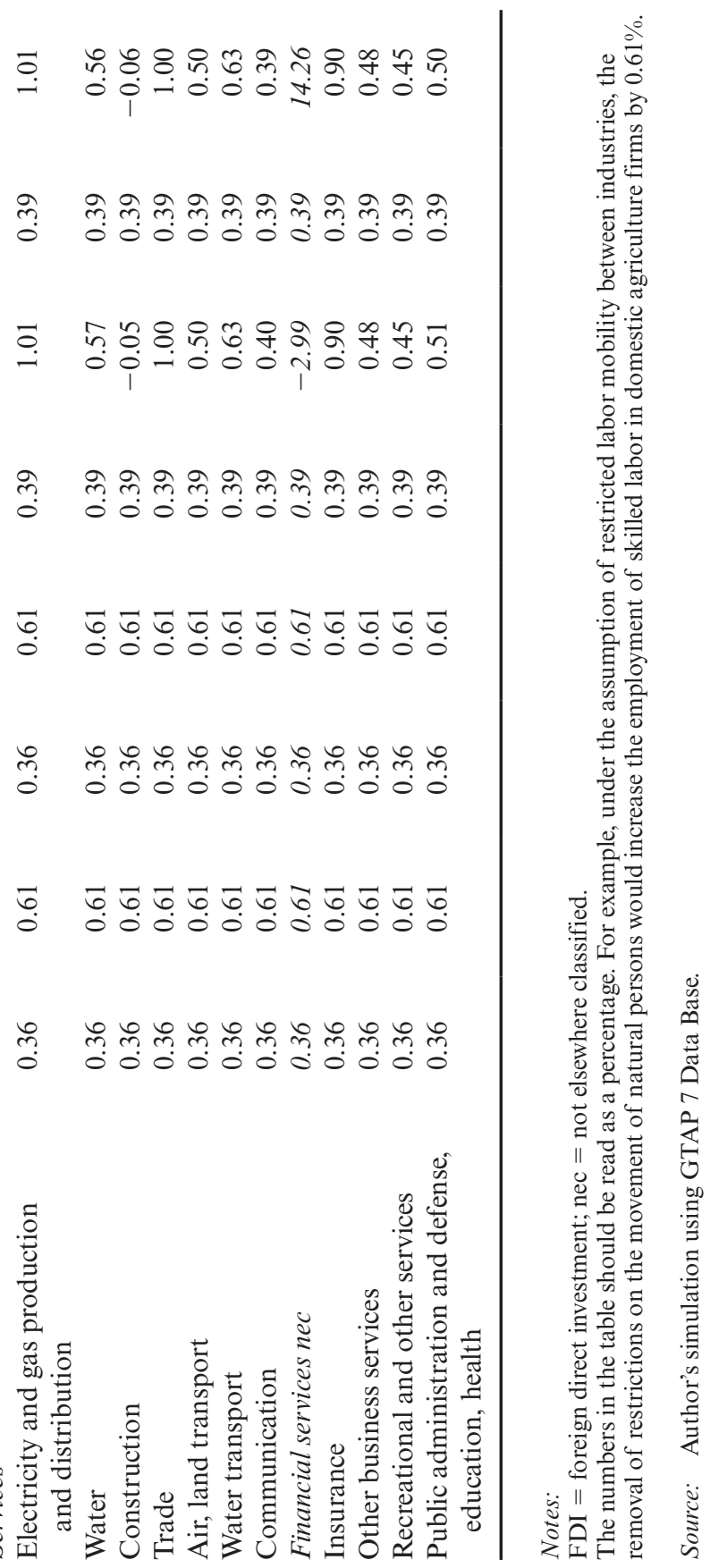


industry will be met by both an increase in labor supply and the absorption of labor from industries with lower labor costs. This process continues until there is no arbitrage in labor price across industries. As a result, we observe various levels of employment growth in skilled labor across industries. In domestic financial institutions, skilled labor is substituted by unskilled labor-as the price of skilled labor is relatively more expensive than unskilled labor, skilled labor employment drops 3\%. By contrast, in FDI counterparts, skilled labor is relatively less expensive than unskilled labor, so skilled labor employment increases $14.26 \%$. In other industries, the highest employment growth for skilled labor is in electricity, gas production and distribution; trade; and insurance, while the least occurs in coal, oil, gas mining; other mining; and agriculture. For ASEAN as a whole, trade reform expands total employment by $0.47 \%$, higher than labor mobility is restricted.

\section{CONCLUSIONS}

Using the FTAP-ASEAN model and GTAP 7 Data Base, this chapter shows that removing restrictions on the movement of natural persons in ASEAN's banking sector could have non-trivial impacts on output and employment across industries regardless of labor mobility assumptions. Although removing restrictions on the movement of individual bank personnel crowds out domestic financial institutions, this trade reform would expand production and employment in all industries. The benefits of trade reform would be even higher with unrestricted skilled labor mobility across industries.

Freeing skilled labor mobility by removing restrictions on the movement of natural persons across countries in the region would make skilled labor more accessible and affordable. This trade reform would mostly benefit employment in financial services and industries with the lowest relative price of labor to capital. Services would gain most in terms of job creation and would also absorb most of the increased labor supply - followed by manufacturing and agriculture and mining.

Our results suggest that removing restrictions on the movement of natural persons and facilitating labor mobility will help mobilize a significant proportion of labor in ASEAN's informal market and help absorb the growing labor force as well. The results support policies that will allow freer flows of skilled labor under the ASEAN Economic Community. It makes sense that restrictions on labor mobility in banking should be removed.

Apart from the banking industry, restrictions on labor mobility remain pervasive across services. There is room for further research to compare the impact of freeing up labor mobility across different services sectors.

Given our modelling features, the projected results presented here need 
to be interpreted with some caveats. First, we assume full employment. In most ASEAN countries, unemployment remains high and there are transaction costs of moving labor from one sector to another. The employment change due to trade reform is likely smaller in the short term than projected results in the long run. Second, we assume the ratio of skilled to unskilled labor is unchanged before and after restrictions are removed. In the long run, with better technology, education and training, demand for skilled labor will rise faster than unskilled labor demand. Further research that takes into account unemployment and the increasing ratio of skilled to unskilled labor is thus needed.

\section{NOTES}

* The author would like to thank Ha Pham for his constructive comments and suggestions.

1. The Movement of National Persons is one of four modes of services trade identified by the WTO GTAS. For example, a foreign national provides a service within economy A as an independent supplier (such as a consultant or health worker) or employee of a service supplier (like consultancy firms, hospitals, or construction companies).

2. Cambodia, the Lao People's Democratic Republic and Viet Nam committed to remove restrictions on (i) acceptance of deposits and other repayable funds from the public; (ii) all types of lending; (iii) financial leasing; (iv) payment and money transmission services; and (v) guarantees and commitments. Myanmar also committed itself to removing the last restriction.

3. Compared to GTAP 9 Data Base, GTAP 7 has 37 fewer regions but is sufficient for this study.

\section{REFERENCES}

Almekinders, G., S. Fukuda, A. Mourmouras, J. Zhou, and Y.S. Zhou (2015), ASEAN Financial Integration, Washington, DC: International Monetary Fund.

Asian Development Bank (2013), The Road to ASEAN Financial Integration: A combined Study on Assessing the Financial Landscape and Formulating Milestones for Monetary and Financial Integration in ASEAN, Manila: Asian Development Bank.

Benston, G.J. and G.G. Kaufman (1996), 'The Appropriate Role of Bank Regulation'. The Economic Journal, 106(436): 688-97.

Dee, P. (2005), 'A Compendium of Barriers to Services Trade', Paper prepared for the World Bank.

Dee, P. (2010), 'FTAP Model: Version 2_7a', Canberra, Crawford School of Public Policy.

Dee P. and H. Dinh (2008), 'The Sectoral Impact of Barriers to Trade in Insurance: A Cost- and Profit-based Approach', Setting Priorities for Services Trade Reform Conference, Australian National University, November.

Dee P. and H. Dinh (2009), 'Barriers to Trade in Health and Financial Services in ASEAN', ERIA Discussion Paper. 
Dinh, H. (2008), 'Regulatory Barriers to Trade in Banking Services', Canberra, Crawford School of Public Policy, Australian National University.

Dinh, H. (2011), 'On Regulatory Barriers to Trade in Banking Services. PhD diss., Australian National University.

Dinh, H. (2012), 'Economy-Wide Impacts of Liberalization in the Vietnamese Banking Sector.' In: Sauvé, P., Pasadilla, G., and Mikic, M. (eds), Service Sectors Reform: Asia-Pacific Perspectives, Tokyo/Bangkok: ADB Institute and ArTNET.

Dinh, H. (2013), 'Impact of Regulatory Barriers to Trade in Banking Services.' In: Dee, P. (ed.), Priorities and Pathways in Services Trade Reform: Part 1-Modeling and Quantitative Studies, Singapore: World Scientific.

Francois, J.F., B. McDonald, and H. Nordstrom (1995), 'Assessing the Uruguay Round.' In: Martin, W. and Winters, L.A. (eds), The Uruguay Round and the Developing Economies, Washington, DC: World Bank, 117-214.

Gowland, D.H. (1990), The Regulation of Financial Markets in the 1990s, Aldershot, UK and Brookfield, VT, USA: Edward Elgar Publishing.

Hanslow, K., T. Phamduc, and G. Verikios (2000), 'The Structure of the FTAP Model'. Economic Analysis, 27, 30.

Llewellyn, D.T. (1986), The Regulation and Supervision of Financial Institutions, London: Institute of Bankers.

Llewellyn, D.T. (1999), 'The Economic Rationale for Financial Regulation', Financial Services Authority (FSA) Occasional Paper Series 1, London.

McDougall, R.A. (1993), 'Incorporating International Capital Mobility into SALTER', Salter Working Paper 21, Canberra: Industry Commission.

McGuire, G. and M. Schuele (2000), 'Restrictiveness of International Trade in Banking Services.' In: Findlay, C. and Warren, T. (eds), Impediments to Trade in Services: Measurement and Policy Implications, London and New York: Routledge.

Narayanan, B.G. and T.L. Walmsley (2008), Global Trade, Assistance, and Production: The GTAP 7 Data Base, West Lafayette, IN: Center for Global Trade Analysis, Purdue University.

Papademetriou, D.G., G. Sugiyarto, D.R. Mendoza, and B. Salant (2015), Achieving Skill Mobility in the ASEAN Economic Community: Challenges, Opportunities, and Policy Implications, Manila: Asian Development Bank.

Petri, P.A. (1997), 'Foreign Direct Investment in a Computable General Equilibrium Framework.' https://ssrn.com/abstract $=1549616$ or http://dx.doi.org/10.2139/ssrn .1549616 .

Verikios, G. and K. Hanslow (1999), 'Modelling the Effects Of Implementing the Uruguay Round: A Comparison Using the GTAP Model under Alternative Treatments Of International Capital Mobility.' Second Annual Conference on Global Economic Analysis, Denmark, Citeseer, 20-22.

Verikios, G. and X-G. Zhang (2000), 'Sectoral Impact of Liberalising Trade in Services.' Third Conference on Global Economic Analysis, Melbourne.

Warren, T. and C. Findlay (eds) (2000), Measuring Impediments to Trade in Services, Washington, DC: Brookings Institution.

World Bank (undated), 'Questionnaires to Assess Services Trade Policy and Performance: Long Version', Washington, DC: World Bank.

Yamanaka, T. (2013), 'Integration of the ASEAN Banking Sector', Institute for International Monetary Affairs Newsletter, December 18. 


\section{APPENDIX 5A.1 THE FTAP MODEL}

In order to measure the economy-wide effects of removing restrictions on the movement of natural persons in the ASEAN banking sector, it is important to use a model capable of tracing flow-on effects of each policy change to all other sectors within and across countries. One available model is the Global Trade Analysis Project (GTAP) model - a multi-regional and multi-sectoral computable general equilibrium model. However, the GTAP model does not reflect prevailing trade barriers in banking services, preventing an impact assessment of trade liberalization. The static version of this model also does not include a treatment of foreign ownership, making it impossible to differentiate the flow-on effects of liberalizing restrictions on domestic banks from those on foreign banks.

The FTAP model deals with these limitations. Following Hanslow et al. (2000), this appendix describes the structure of the FTAP model - a comparative static, computable general equilibrium model of the world economy that was developed in stages from the GTAP model. The key contribution of FTAP is that it includes a treatment of foreign direct investment (FDI) on a bilateral basis. In addition, FTAP has extra coding to facilitate analyzing trade liberalization in services. For example, it allows the revenue from the tax equivalents of services trade barriers to flow to the private sector rather than to the government. It incorporates increasing returns to scale and large-group monopolistic competition in all sectors. And it allows for capital accumulation and international borrowing and lending.

In FTAP, agents demand commodities based upon location and ownership of individual firms as shown in Figure 5A.1. End-user agentshouseholds and governments - choose among final goods and services, while firms choose among intermediate inputs, investment goods, and primary factors (land, skilled and unskilled labor, capital, and natural resources). Agents in FTAP are assumed to make choices first among commodities from domestic and foreign locations as in GTAP, but with a different Constant Elasticity of Substitution (CES) elasticity of 5. The import of goods or services is then selected among foreign locations with a CES elasticity of 10. FTAP then assumes that agents make choices among products or services by ownership with a CES elasticity of 10, after making a decision regarding location. Finally, agents make choices among individual firms within a particular location and ownership with a CES elasticity of 15. These higher elasticities in FTAP compared with those in GTAP accord better with the notion of firm-level product differentiation associated with large-group monopolistic competition (Francois et al. 1995). They are also more consistent with engineering studies of the extent of economies of scale, and hence product differentiation. 


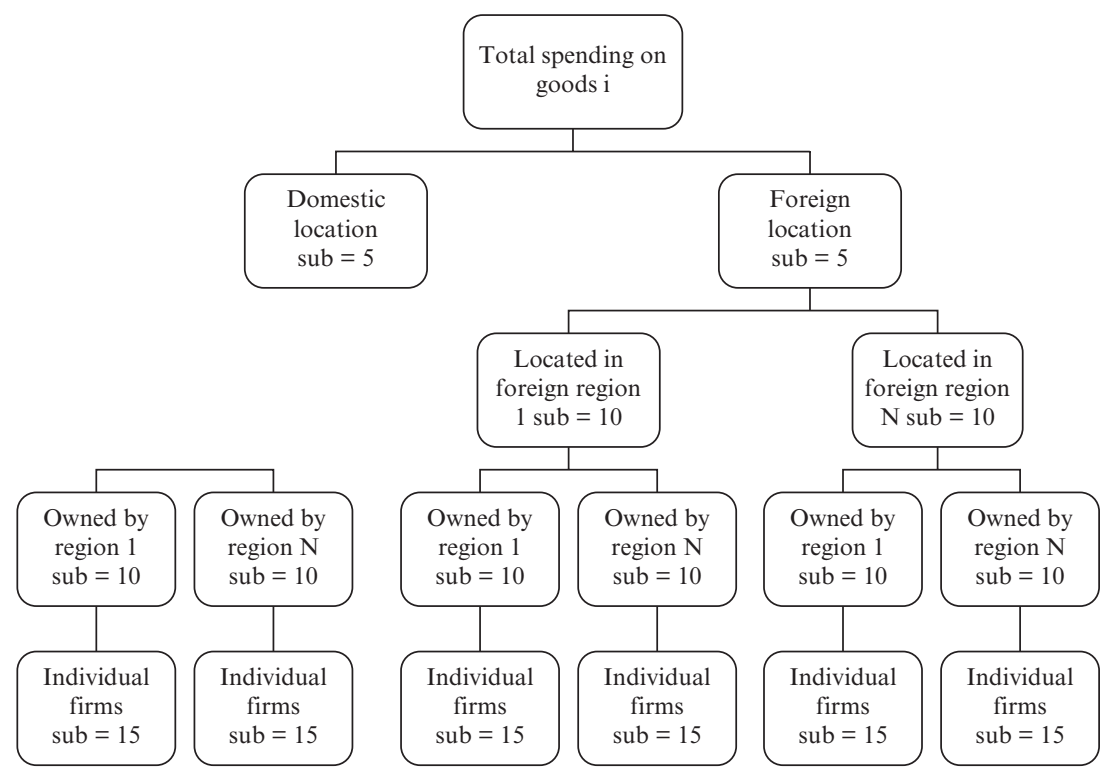

Note: $\quad$ CES $=$ Constant Elasticity of Substitution.

Source: Adapted from Figure 2.2 of Hanslow et al. (2000).

\section{Figure 5A.1 CES nesting structure of commodity preferences in a host country}

Following Petri (1997), choices for allocating wealth in FTAP are first made across types of asset — bonds, land, natural resources, and capital — with a Constant Elasticity of Transformation (CET) elasticity of 1. As land and natural resources are fixed and perfectly immobile between regions, the choice of wealth is really between bonds and capital. In FTAP, the choice of bonds does not depend on who issues them, implying perfectly arbitrage in the rate of return on bonds. The choice of capital is first made among sectors (various primary, secondary, and tertiary sectors) with a CET of 1.2. The choice is then made among locations with a CET of 1.3. When a foreign location is chosen, the choice is finally made among specific foreign regions with a CET of 1.4. This nested structure of capital choice reflects the assumption of imperfect capital mobility between regions and between sectors within each region. Although values of the chosen CET parameters at each "node" of the nesting structure seem to be small, there is a great degree of flexibility in the way that choices at the final level are made. The semi-elasticity of transformation between foreign locations can easily 


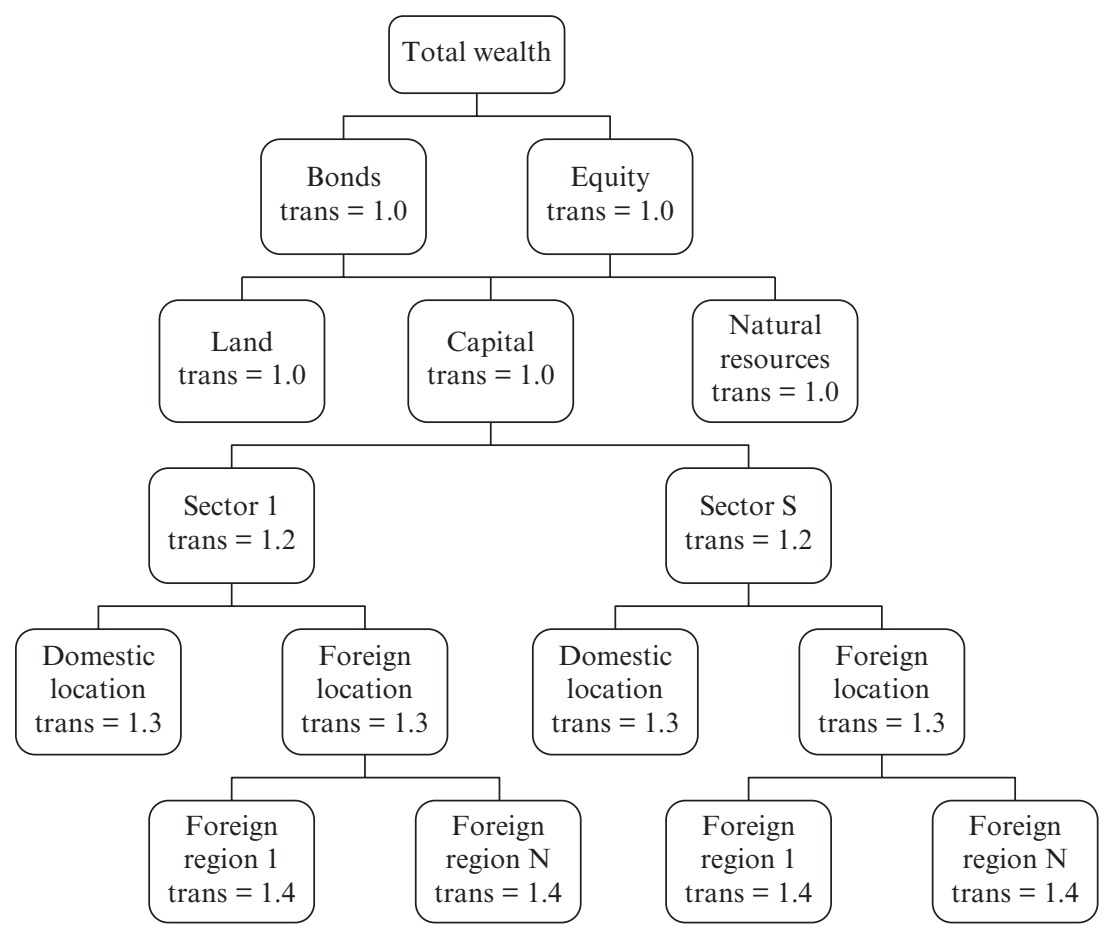

Note: $\quad$ CET $=$ Constant Elasticity of Transformation.

Source: Adapted from Figure 2.2 of Hanslow et al. (2000).

\section{Figure 5A.2 CET nesting structure of wealth supply in a home region}

reach 20 - and even up to 60 (Hanslow et al. 2000). The variation across regions in the implied elasticity comes from both the number of nests and the different initial shares of assets in various regional portfolios.

In FTAP, it is assumed that the current period investment, which is formed from savings, can be added up to the next period capital stock, allowing capital stocks to accumulate over time. It is also assumed that net bond holdings of each region can adjust to finance the expansion of capital that cannot be financed by domestic savings. This treatment of capital enables FTAP to provide a long-term snapshot view of the economy-wide effects of trade liberalization ten years after the reform has occurred. This treatment of international capital mobility was developed by McDougall (1993) and incorporated into GTAP by Verikios and Hanslow (1999). The structure of preferences for investors is depicted in Figure 5A.2. 


\section{Table 5A.1 List of aggregated sectors for simulation}

\begin{tabular}{|c|c|c|}
\hline ID & Sector & Description \\
\hline 1 & Agriculture & $\begin{array}{l}\text { Paddy Rice: rice, husked and un-husked. Wheat: wheat } \\
\text { and meslin. Other Grains: maize (corn), barley, rye, oats, } \\
\text { other cereals, cassava, truffles. Oilseeds: oilseeds and } \\
\text { oleaginous fruit; soybeans, copra. Cane \& Beet: sugarcane } \\
\text { and sugar beet. Plant Fibers: cotton, flax, hemp, sisal } \\
\text { and other raw vegetable materials used in textiles. Other } \\
\text { Crops: live plants; cut flowers and flower buds; flower } \\
\text { seeds and fruit seeds; vegetable seeds, beverage and spice } \\
\text { crops, unmanufactured tobacco, cereal straw and husks, } \\
\text { unprepared, whether or not chopped, ground, pressed } \\
\text { or in the form of pellets; Swedes, mangolds, fodder } \\
\text { roots, hay, lucerne (alfalfa), clover, sainfoin, forage kale, } \\
\text { lupines, vetches and similar forage products, whether or } \\
\text { not in the form of pellets, plants and parts of plants used } \\
\text { primarily in perfumery, in pharmacy, or for insecticidal, } \\
\text { fungicidal or similar purposes, sugar beet seed and seeds } \\
\text { of forage plants, other raw vegetable materials. Cattle: } \\
\text { cattle, sheep, goats, horses, asses, mules, and hinnies; and } \\
\text { semen thereof. Other Animal Products: swine, poultry } \\
\text { and other live animals; eggs, in shell (fresh or cooked), } \\
\text { natural honey, snails (fresh or preserved) except sea snails; } \\
\text { frogs' legs, edible products of animal origin nec, hides, } \\
\text { skins and furskins, raw hides and skins, insect waxes and } \\
\text { spermaceti, whether or not refined or colored. Raw milk. } \\
\text { Wool: wool, silk, and other raw animal materials used in } \\
\text { textile. Fishing: hunting, trapping and game propagation } \\
\text { including related service activities, fishing, fish farms; } \\
\text { service activities incidental to fishing }\end{array}$ \\
\hline 2 & Forestry & Forestry: forestry, logging and related service activities \\
\hline 3 & $\begin{array}{l}\text { Coal, oil, gas } \\
\text { mining }\end{array}$ & $\begin{array}{l}\text { Coal: mining and agglomeration of hard coal, lignite } \\
\text { and peat. Oil: extraction of crude petroleum and natural } \\
\text { gas (part), service activities incidental to oil and gas } \\
\text { extraction excluding surveying (part). Gas: extraction of } \\
\text { crude petroleum and natural gas (part), service activities } \\
\text { incidental to oil and gas extraction excluding surveying } \\
\text { (part) }\end{array}$ \\
\hline 4 & Other mining & $\begin{array}{l}\text { Other Mining: mining of metal ores, uranium, gems; } \\
\text { other mining and quarrying }\end{array}$ \\
\hline 5 & $\begin{array}{l}\text { Food and } \\
\text { beverages } \\
\text { and tobacco } \\
\text { manufacture }\end{array}$ & $\begin{array}{l}\text { Cattle Meat: fresh or chilled meat and edible offal of } \\
\text { cattle, sheep, goats, horses, asses, mules, and hinnies. Raw } \\
\text { fats or grease from any animal or bird. Other Meat: pig } \\
\text { meat and offal. Preserves and preparations of meat, }\end{array}$ \\
\hline
\end{tabular}


Table 5A.1 (continued)

\begin{tabular}{|c|c|c|}
\hline ID & Sector & Description \\
\hline & & $\begin{array}{l}\text { meat offal or blood, flours, meals and pellets of meat or } \\
\text { inedible meat offal; greaves. Vegetable Oils: crude and } \\
\text { refined oils of soya-bean, maize (corn), olive, sesame, } \\
\text { groundnut, olive, sunflower-seed, safflower, cotton- } \\
\text { seed, rape, colza and canola, mustard, coconut palm, } \\
\text { palm kernel, castor, tung jojoba, babassu and linseed, } \\
\text { perhaps partly or wholly hydrogenated, inter-esterified, } \\
\text { re-esterified or elaidinized. Also margarine and similar } \\
\text { preparations, animal or vegetable waxes, fats and oils } \\
\text { and their fractions, cotton linters, oil-cake and other } \\
\text { solid residues resulting from the extraction of vegetable } \\
\text { fats or oils; flours and meals of oilseeds or oleaginous } \\
\text { fruits, except those of mustard; degras and other } \\
\text { residues resulting from the treatment of fatty substances } \\
\text { or animal or vegetable waxes. Milk: dairy products. } \\
\text { Processed Rice: rice, semi- or wholly milled. Sugar Other } \\
\text { Food: prepared and preserved fish or vegetables, fruit } \\
\text { juices and vegetable juices, prepared and preserved fruit } \\
\text { and nuts, all cereal flours, groats, meal and pellets of } \\
\text { wheat, cereal groats, meal and pellets nec; other cereal } \\
\text { grain products (including corn flakes); other vegetable } \\
\text { flours and meals; mixes and doughs for the preparation } \\
\text { of bakers' wares, starches and starch products; sugars } \\
\text { and sugar syrups nec; preparations used in animal } \\
\text { feeding; bakery products, cocoa, chocolate and sugar } \\
\text { confectionery; macaroni, noodles, couscous and similar } \\
\text { farinaceous products; food products nec. Beverages and } \\
\text { Tobacco products }\end{array}$ \\
\hline 6 & Textiles & Textiles: textiles and man-made fibers \\
\hline 7 & Wearing apparel & Wearing Apparel: clothing, dressing and dyeing of fur \\
\hline 8 & Leather products & $\begin{array}{l}\text { Leather: tanning and dressing of leather; luggage, } \\
\text { handbags, saddlery, harness and footwear }\end{array}$ \\
\hline 9 & Wood products & $\begin{array}{l}\text { Lumber: wood and products of wood and cork, except } \\
\text { furniture; articles of straw and plaiting materials }\end{array}$ \\
\hline 10 & $\begin{array}{l}\text { Paper products, } \\
\text { publishing }\end{array}$ & $\begin{array}{l}\text { Paper \& Paper Products: includes publishing, printing } \\
\text { and reproduction of recorded media }\end{array}$ \\
\hline 11 & $\begin{array}{l}\text { Petroleum, coal } \\
\text { products }\end{array}$ & $\begin{array}{l}\text { Petroleum \& Coke: coke oven products, refined } \\
\text { petroleum products, processing of nuclear fuel }\end{array}$ \\
\hline 12 & $\begin{array}{l}\text { Chemical, rubber, } \\
\text { plastic products }\end{array}$ & $\begin{array}{l}\text { Chemical Rubber Products: basic chemicals, other } \\
\text { chemical products, rubber and plastics products }\end{array}$ \\
\hline 13 & $\begin{array}{l}\text { Mineral products } \\
\text { nec }\end{array}$ & $\begin{array}{l}\text { Non-Metallic Minerals: cement, plaster, lime, gravel, } \\
\text { concrete }\end{array}$ \\
\hline
\end{tabular}


Table 5A.1 (continued)

\begin{tabular}{|c|c|c|}
\hline ID & Sector & Description \\
\hline 14 & $\begin{array}{l}\text { Iron, steel, and } \\
\text { non-ferrous } \\
\text { metals }\end{array}$ & $\begin{array}{l}\text { Iron \& Steel: basic production and casting. Non-Ferrous } \\
\text { Metals: production and casting of copper, aluminum, } \\
\text { zinc, lead, gold, and silver }\end{array}$ \\
\hline 15 & $\begin{array}{l}\text { Fabricated metal } \\
\text { products }\end{array}$ & $\begin{array}{l}\text { Fabricated Metal Products: sheet metal products, but not } \\
\text { machinery and equipment }\end{array}$ \\
\hline 16 & $\begin{array}{l}\text { Motor vehicles } \\
\text { and parts }\end{array}$ & Motor Vehicles: cars, lorries, trailers and semi-trailers \\
\hline 17 & $\begin{array}{l}\text { Transport } \\
\text { equipment nec }\end{array}$ & $\begin{array}{l}\text { Other Transport Equipment: manufacture of other } \\
\text { transport equipment }\end{array}$ \\
\hline 18 & $\begin{array}{l}\text { Electronic } \\
\text { equipment }\end{array}$ & $\begin{array}{l}\text { Electronic Equipment: office, accounting and computing } \\
\text { machinery, radio, television and communication } \\
\text { equipment and apparatus }\end{array}$ \\
\hline 19 & $\begin{array}{l}\text { Machinery and } \\
\text { equipment nec }\end{array}$ & $\begin{array}{l}\text { Other Machinery \& Equipment: electrical machinery } \\
\text { and apparatus nec; medical, precision and optical } \\
\text { instruments; watches and clocks }\end{array}$ \\
\hline 20 & $\begin{array}{l}\text { Manufactures } \\
\text { nec }\end{array}$ & Other Manufacturing: includes recycling \\
\hline 21 & $\begin{array}{l}\text { Electricity and } \\
\text { gas production } \\
\text { and distribution }\end{array}$ & $\begin{array}{l}\text { Electricity: production, collection and distribution. } \\
\text { Gas Distribution: distribution of gaseous fuels through } \\
\text { mains; steam and hot water supply }\end{array}$ \\
\hline 22 & Water & Water: collection, purification and distribution \\
\hline 23 & Construction & Construction: building houses factories offices and roads \\
\hline 24 & Trade & $\begin{array}{l}\text { Trade: all retail sales; wholesale trade and commission } \\
\text { trade; hotels and restaurants; repairs of motor vehicles } \\
\text { and personal and household goods; retail sale of } \\
\text { automotive fuel }\end{array}$ \\
\hline 25 & $\begin{array}{l}\text { Air, land } \\
\text { transport }\end{array}$ & $\begin{array}{l}\text { Other Transport: road, rail; pipelines, auxiliary transport } \\
\text { activities; travel agencies. Air transport }\end{array}$ \\
\hline 26 & Water transport & Water transport \\
\hline 27 & Communication & Communications: post and telecommunications \\
\hline 28 & $\begin{array}{l}\text { Financial services } \\
\text { nec }\end{array}$ & $\begin{array}{l}\text { Other Financial Intermediation: includes auxiliary } \\
\text { activities but not insurance and pension funding (see } \\
\text { next) }\end{array}$ \\
\hline 29 & Insurance & $\begin{array}{l}\text { Insurance: includes pension funding, except compulsory } \\
\text { social security }\end{array}$ \\
\hline 30 & $\begin{array}{l}\text { Other business } \\
\text { services }\end{array}$ & $\begin{array}{l}\text { Other Business Services: real estate, renting and business } \\
\text { activities. Dwellings: ownership of dwellings (imputed } \\
\text { rents of houses occupied by owners) }\end{array}$ \\
\hline 31 & $\begin{array}{l}\text { Recreational and } \\
\text { other services }\end{array}$ & $\begin{array}{l}\text { Recreation \& Other Services: recreational, cultural } \\
\text { and sporting activities, other service activities; private } \\
\text { households with employed persons (servants) }\end{array}$ \\
\hline
\end{tabular}


Table 5A.1 (continued)

\begin{tabular}{lll}
\hline ID & Sector & Description \\
\hline 32 & $\begin{array}{l}\text { Public } \\
\text { administration } \\
\text { and defense, } \\
\text { education, health }\end{array}$ & $\begin{array}{l}\text { Other Services (Government): public administration } \\
\text { and defense; compulsory social security, education, } \\
\text { health and social work; sewage and refuse disposal, } \\
\text { sanitation and similar activities; activities of membership } \\
\text { organizations nec; extra-territorial organizations and } \\
\text { bodies }\end{array}$ \\
\hline
\end{tabular}

Note: $\quad$ nec $=$ not elsewhere classified.

Source: Adapted from Narayanan and Walmsley (2008).

With a treatment of ownership in the model, FTAP is able to control for many benefits of FDI that GTAP cannot. For example, FTAP reflects how FDI can relax domestic constraints on capital. It also captures how FDI contributes to product diversification as well as product specialization, where a particular industry has a comparative advantage. However, the current FTAP model has yet to capture the transfer of skills, technology, and management know-how from FDI to local firms.

It is also important to note some assumptions about factors of production in FTAP. Skilled and unskilled workers are perfectly mobile between industries. Consequently, prices of each type of labor are uniform across industries within each economy. Because of the behavior of asset holders, capital is less than perfectly transformable between industries, thus allowing rental prices to differ across industries. Land is supplied with a transformation elasticity of 1 , as this factor is used only in the agricultural sector. The elasticity of transformation of natural resources between industries is so small that the supply of this factor to each industry is essentially fixed. (Natural resources are inputs in agriculture; forestry, coal, oil, and gas mining; and other mining.) This assumption comes from the fact that natural resources are irrecoverable; when it is already used in this industry, it cannot be transferred to another industry. Consequently, the rental prices of land and natural resources can vary from industry to industry. This chapter uses the FTAP model, Version 2_7a by Dee (2010) to measure the economy-wide output and employment effects of trade liberalization in the ASEAN banking sector. 